\title{
THE DIGGER WASPS OF NORTH AMERICA OF THE GENUS PODALONIA (PSAMMOPHILA)
}

\author{
By H. T. Fernald, \\ Of the Massachusetts Agricultural Experiment Station, Amherst
}

\section{INTRODUCTION}

The studies presented in this paper were begun a number of years ago and have been continued in the intervals between the other duties of the writer. That they were not completed earlier is due, first, to those duties; and second, to the great amount of variation present in the insects concerned. This variation has made necessary the examination, over and over, of thousands of specimens and their study in relation to the climatic conditions of the localities where they were captured, which has required much time.

This paper has been based on the remarkably fine collection of the genus in the United States National Museum, supplemented by loans from more than 50 other museums and private collections. During nearly six months spent in Europe for the purpose, the types there were carefully studied and compared with material taken from this country, and almost every type of the North American species, both in Podalonia and in Sphex (Ammophila Authors), which is still in existence there, was found and examined.

This paper deals with the relatively small genus Podalonia Spinola; a second on the much larger genus Sphex is well along, and it is the hope of the writer that it will soon be ready for publication.

To all those who loaned specimens for study and who have so patiently waited year after year for their return, the writer desires to express his grateful appreciation; to name them would take an unwarranted amount of space. But he desires to express his thanks in particular to the officers of the United States National Museum; of the American Entomological Society, and of the Museum of Comparative Zoölogy of Harvard Unjversity for the opportunities given him to examine the types of species belonging to the group, in those collections; and to S. A. Rohwer, of the United States Bureau of Entomology, for his constant cooperation, his kind suggestions, and the aid received from the free statement of his views on points which have seemed debatable.

No. 268I.-Proceedings U. S. National Museum. Vol. 7I, Art 9. 


\section{GENERAL STRUCTURE}

An insect of the genus Podalonia is, as a rule at least, under an inch in length. In most cases the body is rather slender and the legs long. The head is quite large, rounded from the front, rather transverse oblong with rounded corners, viewed from above, and quite a portion of it is taken up by the large, compound eyes. Between these the surface is quite flat or even depressed above the antennal articulations, but below these the clypeus in the females may be strongly swollen centrally. The cheeks behind the compound eyes may be quite thick above, contributing largely to the oblong outline, but below this they may narrow quickly or slowly.

The prothorax, for convenience, may be divided, above and from the side, into the neck, the rather slender portion to which, at its front end, the head is joined; and the collar. Behind the neck the segment widens and rises more or less abruptly till about as high as the mesonotum; it then rounds backward, then downward somewhat to articulate with the front margin of the mesonotum. At the sides, the segment also widens somewhat and articulates with the front corners of the mesonotum. It is this elevated region above and its sides, just described, to which the term collar is here applied. At the side, close to the front corner of the mesonotum, is a backward extension of the prothorax nearly circular in outline, slightly swollen so that it somewhat resembles a tegula, and fringed behind with a thick row of short, fine hairs. This projection, here called the prothoracic lobe, lies over a somewhat depressed area of the mesopleuron, concealing a spiracle there.

The other portions of the thorax call for little in the way of description. Posterior and dorsal to the thorax proper, however, and so compactly joined to it as to form a part of the thoracic mass, is the propodeum or first true abdominal segment, which requires consideration. The dorsal portion of this segment appears to articulate with the hind margin of the postscutellum by a transverse suture. About at the point where the plate begins to bend sharply downward to form the sides of the body, its structure changes in appearance, marking out lateral limits to the dorsal portion. These lines run backward just above the spiracle located on the side, sometimes bending inward slightly around the dorsal margin of the spiracle, then bending laterally more or less before curving inward to form a pointed tip to this area. The outline of the dorsal area thus limited is quite like a shield and is here spoken of as the propodeal disk or shield. Its surface varies in different species and to some extent in different individuals of the same species but, in general, shows punctures and ridges. In their simplest condition the ridges tend to be transverse anteriorly, then more oblique, running back and out from 
the median line posteriorly, with the area near the tip of the shield liable to show an inclination to transverse ridges again. The punctures may be coarse, medium, or fine. When coarse and close together, which is particularly liable to be the case anteriorly and near the median line, all traces of the ridges may be lost and a confused appearance of the surface results. Where a tendency for the punctures to lie in transverse rows develops, irregular transverse ridges may develop between the rows of punctures. The punctures are liable to become smaller at the side behind the spiracle and near the tip, and here the ridges are generally finer. The posterior end of the propodeum drops off sharply from the tip of the shield to the articulation of the petiole. Between these points is often a small indentation or fovea, varying in size. The surface of the end is punctured and may be more or less ridged, the ridges, when present, being most evident running downward at the sides of the petiole. The sides of the propodeum are directly continuous with the end and resemble it in markings, though there is a greater tendency to the production of ridges on the sides than at the end or on the shield, particularly near the propodeo-mesopleural suture, the ridges running downward and often somewhat forward.

Where the sides of the propodeum are plainly ridged, this condition is likely to continue on to the metapleuron, the ridges running less downward but more nearly along the body. A small, more or less separated portion of this plate, lying at its upper anterior end beneath the hind wing, is often nearly or quite free from punctures and more noticeably ridged than the other portions. The ridges may extend entirely across the plate and continue more or less on the mesopleuron, or may end at the meso-metapleural suture. The mesopleuron is generally quite closely and coarsely punctured, but ridges on it are usually restricted to that portion adjacent to the metapleuron. A somewhat triangular portion beneath the fore wing may show few punctures and be rather distinctly ridged.

The main mass of the abdomen is connected with the propodeum (and thorax) by a slender, cylindrical stalk, the petiole. In this genus the petiole consists of only one segment (two in Sphex) and is apparently only the sternum. At its front end a muscle, attached just above its articulation to the propodeum, attaches to the upper side of the petiole a short distance out and acts as a levator muscle. At its posterior end the petiole broadens out below, forming a sort of flat, spatulate area. Over this portion is apparently the notum of the segment. This rises quite rapidly from the axial line of the petiole ("somewhat bell-shaped," Kohl) and is quite wide, its lateral margin hanging down over the ventral plate. In this notum is a spiracle located in front of, or at most, at the middle of the length of the plate. 
Behind this comes the remainder of the abdominal mass (the body behind the slender portion of the petiole is, for convenience, called the abdomen in this paper) having the usual characters. The surface is smooth or, at most, only minutely sericeous, except in the male of one species (argentifrons), and with a few rather short, scattered erect hairs. Above, these are almost or entirely on the terminal plate. Below, they are most numerous on the terminal plate, but a few may be present on the more anterior sterna. The form of the tip differs according to the sex (see Sex Distinctions). The posterior outline of the last ventral abdominal plate varies somewhat in different species, but this is, unfortunately, also the case in examples of the same species, which prevents use of this feature as a trustworthy distinction for species.

The wings show little difference from those of related groups. The tegula is generally smooth and glistening. The larger wing veins are generally darker than the smaller ones and usually dark brown or piceous. The wing surface varies from hyaline, through various stages of darkening, to fuliginous, which is accompanied by a deep blue or violet reflection. The depth of this darkening is usually greatest toward the tip of the wing beyond the ends of the veins and cells.

The veins and cells themselves vary greatly, particularly the radial and second and third cubital cells. The radial cell may be rather long for its width, or short and broader; the transverse cubital veins may vary somewhat in their distance apart and in the paths they follow, resulting in differently proportioned cubital cells, particularly the third cubital. Modification of vein arrangement, the introduction or omission, partial or entire, of veins often occurs, giving numerous abnormalities such as a petiolated second cubital cell, etc. Though such variations are usually present on both pairs of wings, this is not always the case, as examples with a petiolated second cubital cell on one side and normal conditions on the other, occur. In general, variations in venation are most frequently found in examples which are below normal size for a species, in small species, and in males.

The legs in this genus, as in all Sphecidae, are rather long. The coxae, trochanters, and femora may bear hairs, usually decreasing in number passing outward along these segments, and some face or faces of them may be more or less sericeous. Spines appear on the tibiae and tarsi, not very long on the tibiae but quite stout. On the tarsi they are usually longer, as compared with the length of the segment, than on the tibiae. The cleaning spine at the tip of the hindtibia has the teeth on the outer half of the spine at least, coarser and more separated than in the genus Sphex. In the females the spines on the outer side of the fore metatarsus are usually seven in number, 
four on the side proper, one on the laterally projecting angle of the segment at its outer end, and two on the end between the one last mentioned and the articulation of the next tarsal segment. In some species, despite variations, these seven spines are long and maintain their diameter nearly to the end, which often appears almost squarely cut off. Between and around the four long spines on the side, other ordinary ones are usually present. Of the four, the first is liable to reduction to about half the length of the others but is often full size. These spines appear to be used as scrapers by the insects in digging holes where their prey and eggs are deposited. Claws are nearly always (always?) light, ferrugineous or even lighter colored in some cases. None of the North American species have toothed claws. The pulvillus is usually large but is greatly reduced or absent in luctuosa.

\section{SURFACE CHARACTERS}

The surface markings on the various skeletal plates show much of interest. Nearly every plate bears a smaller or greater number of indentations or pits (termed punctures), more or less circular in outline, not as deep as the diameter of the hole at the surface. From the bottom of each pit grows a hair, so that the abundance of clothing of an insect can be determined by the abundance of the punctures, even with specimens in which most of the hairs have been worn off. Where the punctures are circular in outline the hairs stand erect, though their outer half may be curved; where the pit enters obliquely, giving it an oval outline, the hairs come out obliquely. Different sizes of punctures are paralleled by different sizes of hairs growing out from them. Pubescence, in the sense used by the writer, does not occur in this genus as a rule, except on the clypeus and lower part of the frons in the males. Here the punctures are small, close together, oblique, and the hairs coming from them are decumbent, forming a smooth, continuous covering lying close to the plate itself.

A still finer grade of marking is so minute that its details are hardly perceptible without higher powers, but with a pocket lens or low powers of the microscope a sort of "bloom," suggesting that on a ripe plum, is evident. Where this is found, the plate beneath shows very fine markings which some writers have indicated by describing the surface as "shagreened." This appears also to consist of the most minute punctures, out of which come very minute, decumbent hairs which show on the body much better at some angles than at others. In some cases, if not viewed at the proper angle, they can not be seen at all. A surface described as sericeous is one produced by the tiny hairs just mentioned. Brownish or grayish sericeous is often met with on the antennal filament and elsewhere. 


\section{MEASUREMENTS}

Various comparative measurements of body parts have been used by different describers of species. These are most often the comparative length of the first two segments of the antennal filament, and the length of the petiole as compared with that of the hind coxa and trochanter taken together.

Several thousand such measurements taken with a filar micrometer indicate that while those of the antennal filament segments may, in some cases, be of value, those of the petiole, as compared with the hind coxa and trochanter, can not often be relied upon.

To obtain such measurements accurately, the measuring limit points must be accurately fixed. The petiole is usually measured from the attachment of the levator muscle on it to the point where the dorsal plate begins at its hinder end. With the coxa and trochanter, however, no common points have been established and the irregular ends of these segments, caused by the irregular sockets, make it impossible to obtain really accurate figures. It is rare that coxa and trochanter are in the same plane and the points of beginning and ending of the measuring can not be made identical in many cases. Variation, too, is found here. In one species the petiole varies, in proportion to the coxa plus trochanter, from 0.62 to 0.89 , and in specimens from the same State between 0.63 and 0.77 . Under the microscope the difficulty of placing the piece to be measured, exactly at right angles to the line of vision, is also met with. Repetitions of measurements of the same specimens have given variations as great as 0.07 , in spite of the utmost care to obtain accuracy, and the final conclusion reached is that the only use which can be made of such measurements is where the petiole is shorter than, or at least no longer than the coxa, as compared with those where it is at least as long as the coxa and half of the trochanter $\mathrm{t}$ aken together.

\section{COLORS AND COLOR VARIATIONS}

These may be perhaps most easily described on the unproved assumption that the insects of this genus were originally entirely black, and in a few species (as luctuosa) this is still the case. Assuming a tendency to the developing of ferruginous, this will first appear on the second abdominal segment and on the middle of the mandible, and its first evidence is a change to black with a reddish tinge which may perhaps be termed piceous. Increase of the ferruginous influence leads to dark red, then to ferruginous proper. As this tendency increases, more abdominal segments become involved until the entire abdomen is ferruginous and, in some cases, even pale ferruginous. This color may spread forward as well as backward, involving the first abdominal segment, but the petiole appears quite resistant to this tendency, and the thoracic mass and head appear to 
be almost always black. The legs, usually black, may yield to the tendency to become ferruginous and then the tarsal segments, tibia and femora assume this color, the last tarsal segment often less so than the others. Approaching the body, the tendency to become ferruginous appears to struggle for ascendency with the tendency to preserve the black, passing out from the thorax. The result is that the coxae and trochanters (except the hind pair) are usually entirely black, and the femora are streaked with black on their proximal halves. The claws in all species are ferruginous of some shade, even in the totally black species.

In the female of argentifrons, the abdomen is a deep blackish blue, and glistening.

The usual color of the hairs is black but they seem to respond to the same influences though more slowly. The more ferruginous species may have pale hairs though this is not a fixed rule. Even a tendency to golden yellow on the clypeal hairs is sometimes noticeable. Pubescence is present only in the males (and on the clypeus of nicholi female) as far as observed, on the clypeus and frons, and is white or "silvery." The minute hairs which produce a "sericeous" surface are usually brownish on the antennal filament but may be white or silvery, or of other colors elsewhere.

There appears to be a close correlation between the area occupied by the ferruginous and the habitat of the insect. Thus, specimens of Podalonia violaceipennis taken near the ocean or large bodies of water have less red and their wings are more fuliginous than those captured inland. In semiarid regions, the area occupied by the red increases; the wings become more nearly hyaline and the veins lighter. In arid regions, much of the abdomen becomes red, the legs tend to piceous in some cases, and the wings may be hyaline. Apparently the influence of humidity on this species closely corresponds to that already described for Sphex procerus (Dahlbom). ${ }^{1}$

\section{SEX DISTINCTIONS}

There are several ways by which the sex in this genus may be determined. When the sting is protruded there is, of course, no difficulty, but if not, the novice may need to look for other characters.

In the males there are 13 antennal segments; there are no long spines on the outer side of the fore metatarsus; the margin of the clypeus extends much farther below a line joining the bottom of the eyes than in the female; the petiole is longer and the tip of the abdomen is rather flattened laterally.

In the female the antenna has 12 segments; there are long external lateral and terminal spines on the fore metatarsus; the margin of the 
clypeus does not extend far below a line drawn between the bottoms of the eyes; the petiole is usually shorter than in the male, and the end of the abdomen is conical.

Hairs may differ in color in the sexes. In some cases the head and body hairs in the female are all black while in the males white hairs occur. In this case they first appear near the hind end of the thoracic mass, then spread forward along the sides of the thorax to the pronotum and even onto the vertex and cheeks on the head. Oftentimes the hairs behind may be entirely white; further forward, black or brown with white tips; and black further forward.

Males nearly always have more black on their bodies than the females. The male Podalonia valida has the tip of the abdomen black.

\section{GEOGRAPHICAL DISTRIBUTION}

Species of this genus occur in Europe, Asia, Africa, Australia? (suspiciosa Smith), South America (bocandei Spinola), and North America. In the last-named country I have examined specimens from as far north as Nova Scotia and Fort McLeod, British Columbia (about latitude $55^{\circ}$ ), and several species occur in different parts of Canada. Southward they are found in all parts of the United States, in Mexico and to Panama though the records of these southern forms (Biologia Centrali-Americana) suggest that in Central America they are mainly inhabitants of elevated districts.

In North America some species are widely distributed; others rather local. Details of distribution are given in connection with the individual species. Maps illustrating the known distribution of four of the more widely distributed species are included as text figures. In these maps the solid black dots stand for actual locality data, while the cross $(x)$ indicates specimens for which only the state was given.

\section{CLASSIFICATION}

One not familiar with the insects of this group will find keys by which they may be traced to the Sphecidae in Comstock's Introduction to Entomology, First Complete Edition, 1924, and on page 963 of that book is a further key leading to the subfamily (there erroneously called tribe) Sphecinae. On page 966 is a brief treatment of the subfamily, but without further classification.

In a previous paper ${ }^{2}$ on another section of this subfamily, the group was considered by me as a family and its divisions were called subfamilies. In my opinion this is a better valuation than that given by Comstock, but to produce continuity in the keys and avoid confusion, the key below accepts Comstock's terms and divides the sub-

${ }_{2}^{2}$ Proc. U. S. Nat. Mus., vol. 31, p. 295, 1906. 
family into tribes. To harmonize this paper with the other, ${ }^{2}$ it is only necessary to change the title of the key on page 308 of that paper ${ }^{2}$ to read: Analytical key to tribes. This key slightly modified, is given below.

ANALYTICAL KEY TO TRIBES

1. Second cubital cell receiving only the first recurrent vein; the second recurrent vein receiv ed by the third cubital cell. (Both recurrent veins are received by the first cubital cell in a few extra-limital forms) _.......... 2 Second cubital cell receiving both recurrent veins, or the second recurrent vein is interstitial with the second transverse cubital. Sometimes the first recurrent is interstitial with the first transverse cubital, or received by the first cubital cell $\ldots \ldots \ldots \ldots$

2. Antennae inserted on the middle of the face; claws with one to six teeth beneath; tibiae spinous; tarsal comb present in female (except in Isodontia).

Chlorionini (Sphecinae of Authors)

Antennae inserted far below the middle of the face; claws simple, either without teeth or with only one small tooth near the middle; tibiae not spinous: tarsal comb in female, absent.

Podiini

3. Claws simple, without teeth (teeth present in some extralimital forms); tibiae more or less spinous; tarsal comb present in female; abdomen more or less elongate; petiole of one, or two segments; cubital vein of hind wing usually originating beyond the transverse median vein.

Sphecini (Ammophilinae of Authors)

Claws with a single tooth beneath, sometimes very minute; rarely without a tooth; tarsal comb in female absent; petiole of one segment; cubital vein of hind wing interstitial with transverse median vein or nearly so _. _....... 4

4. Antennae inserted on middle of face; metathorax with a large $U$-shaped area above; mesopleura not longer than the height of the thorax _._Sceliphronini Antennae inserted far below the middle of the face, on, or just above an imaginary line drawn between bases of the eyes; metathorax without a large $U$-shaped area above; mesopleura much longer than the height of the thorax.

Podiini

In the tribe Sphecini seven genera besides $S p h e x$ have at one time and another been proposed, namely: Ammophila Kirby, 1789; Miscus Jurine, 1807; Psammophila Dahlbom, 1842; Coloptera Lepeletier, 1845; Podalonia Spinola, 1853; Parapsammophila Taschenberg, 1869; Eremochares Gribodo, 1882; and Ceratosphex Rohwer (as a subgenus), 1921. Ammophila, as has already been shown, ${ }^{3}$ can not hold, being a synonym of Sphex ${ }^{4}$ as the genotype of both genera is sabulosa Linnaeus. Miscus appears to have been established solely on the basis of the presence of a petiolated third cubital cell. Jurine says: "Lorsque je remarqui pour la première fois la figure de la troisième cellule cubitale des ailes de ces insectes, je présumai que c'etait une anomalie dépendante de la petitesse de ces Sphex dont je ne devais par tenir compte, mais l'ayant vue dans quatre individus, dont deux sont indigènes, j'ai cru devoir placer ces hyménoptères dans un genre nouveau."

2 Proc. U. S. Nat. Mus., vol. 31, p. 295, 1906.

3 Proc. U. S. Nat. Mus., vol. 31, p. 292-295, 1906.

- Opinion 32 rendered by the International Commission on Zoological Nomenclature, Smithsonian Pub. lication 2013, 1911. 
Variation of this nature in Sphecids is common, and examples are sometimes met with in which there is a petiolated cell on one side while the other is perfect. An examination of about 1,100 specimens of one species of Sphex shows that venation variations are liable to occur either on one or both sides in about one specimen of each hundred, the variation occurring most frequently in the males. Miscus arvensis Dahlbom is such a specimen.

Psammophila was established by Dahlbom for insects of this tribe in which the petiole consists of only one segment. This name being preoccupied, Podalonia takes its place. This will be discussed at greater length later in this paper. Coloptera, proposed by Lepeletier was based as follows: "Caracteres. Ceux des deux genres précédens" (Ammophila and Miscus) "sauf ce qui suit: Deux cellules cubitales seulement." A careful study of the American species of Coloptera reveals no characters separating this insect from Sphex, and the unreliability of venation alone, used for this purpose has just been indicated and will be further demonstrated in the course of this paper.

Parapsammophila, created by Taschenberg, appears to be based largely upon the presence of two teeth on each claw. As no Sphecini with toathed claws have thus far been observed in North America, the validity of this genus need not be considered further here. Eremochares, established by Gribodo, has as its chief reason for existence, the presence of a single tooth on each claw. Ceratosphex has its petiole of two segments and the claws are armed with two teeth. As no species with these characters have been found in North America, this leaves Sphex (Ammophila Authors) and Podalonia as the two genera to be considered in this country.

Whether these are sufficiently distinct to entitle them to be regarded as different is an open question. $\mathrm{Kohl}^{5}$ regards them along with Eremochares, Parapsammophila, Coloptera, etc., as "species groups." They may be considered either as subgenera or genera according to the ideal standards in the minds of different students of the group. Species which might be termed typical in each group are easily recognized and support the valuation of the groups as genera, but in other cases it becomes somewhat difficult to draw the line between them. My personal opinion is that, when a world study of these insects has been made, these groups will be regarded as of at most only subgeneric value. For the purpose of this paper, however, it is most convenient to treat them as genera and deal with Podalonia at this time, leaving Sphex for separate consideration.

ANALYTICAL KEY TO GENERA

1. Petiole consisting of one segment, its dorsal plate quite broad and more or less bell-shaped; comb teeth on hind tibial spine not crowded, rather stout;

s Annalen des k. k. Naturhistorischen Hofmuseums, Wien, vol. 31, p. 228, 1906. 
spiracle on first abdominal notum in front of, or at least not behind, the middle of the plate

Podalonia

Petiole consisting of two segments; comb teeth on hind tibial spine closely packed together, rather slender; spiracle on first abdominal (second petiole segment) notum at or behind the middle

Sphex

\section{Genus PODALONIA Spinola}

The solitary wasps here placed in the genus Podalonia were first separated as a genus by Dahlbom in 1842 under the name Psammophila, and included two species, Psammophila affinis Kirby and Psammophila viatica Linnaeus. Apparently no genotype has ever been designated.

The Linnaean viatica was removed from the Sphecidae by Fabricius and placed in the Pompilidae (Psammocharidae) and, though there is still the Ammophila viatica of De Geer, which is a Psammophila this species is a synonym of Sphex hirsuta Scopoli, De Geer's viatica not being the same species as the Linnaean one. Accordingly, Psammophila affinis Kirby is the genotype of the genus Psammophila.

But Psammophila of Dahlbom is itself a preoccupied name, having been previously used in 1827 in connection with a genus of Mollusks, and another generic name becomes necessary to replace it. This is found in Spinola's genus Podalonia 1853, a genus unintentionally established under most peculiar circumstances. In the course of a discussion upon the making of new genera, based upon what he considered absurdly minor characters, at most of only specific value, Spinola remarks that the genus "Mischus" (Miscus) was established by Jurine for a European Ammophila (campestris) "qui a la troiséme cellule cubitale de l'aile superieure petiolée. Or au même titre il faudrait isoler pareillement un nouveau genre pour celles qui auraient $l a$ seconde cellule cubitale petiolée, comme le mâle inedit que M. Bocandè a rapport de la Guinée et dont la description arrive ici à propos quoique l'espece ne vien pas du Para." Then follows the description of Ammophila bocandei including the following statements: * * * "petiolo ut in Ammoph. arenaria Latr. * * * Alae * * * superiores, cellulis quatuor cubitalibus, prima tertia et quarta, formae consuete, secunda minore triangulare oblique petiolata * * * ." "Il m'en aurait peu couté de construire un nom de genre bien Graecoide et bien significatif, Podalonia par exemple, mais j'ai pense qu'il valait mille fois mieux de relever ces particularities alaires dans les diagnoses des Amm. campestris et Bocandei et de les y laisser pour ce qu'elles sont, pour des characters purement specifiques."

Had it been possible to retain the name Psammophila for the wasps concerned, this name of Spinola's might have always remained as, at most, only a synonym. But with Psammophila no longer available, the availability of Podalonia must be considered. Analyzing the situation, we find that a specific description (bocandei) is given in 
connection with this name; that in this description reference is made to another species known to be a Psammophila; that the structure of the petiole is that of Psammophila; and that the only reason for another generic name is the petiolated second cubital cell. Thus a name proposed only as an illustration of the ease with which a significant generic name could be formed becomes actually available as a substitute for Psammophila. Its standing is that of a monobasic genus, its generic characters to be found among the specific characters given for its genotype, bocandei, and its relation to one other species indicated.

It seems one of the ironies of fate that a name suggested under such circumstances as these and most emphatically rejected by its author, being used only as an illustration, should obtain an accepted standing. Yet no other name, except the unavailable Psammophila has been given to these insects. Thus it seems necessary to violate the evident desire of Spinola and establish Podalonia as a genus in full standing. The whole situation, as regards Spinola, at once brings to mind the case of Ignotus aenigmaticus Slosson (Coleoptera).

GENERIC CHARACTERS

Podalonia, as here considered, may be distinguished most readily from Sphex, in most cases, by the petiole. In Sphex this slender portion involves two segments, the second being larger, though shorter, than the first, and increasing only slightly backward in size. In Podalonia we find only one segment in the petiole, the dorsal plate of this segment (here counted as the first abdominal dorsal plate) being quite large and increasing rapidly in size backward. There are some species, however, in which this plate is rather intermediate between the two conditions and these specimens are liable to be perplexing, and in such cases other characters need consideration. In Podalonia the comb teeth on the longer hind tibial spine are not crowded as closely together as in Sphex and are coarser, and the spiracle on the first abdominal dorsal plate is in front of, or at least not behind, the middle of the length of the plate.

If these characters were absolutely fixed, no difficulty in separating Podalonia and Sphex would be encountered, but in a few cases the spiracle is found slightly behind the middle of the plate in Podalonia and there are degrees of crowding and in the coarseness of the comb teeth which, in individual specimens, may make the determination of the genus difficult in those cases, and final placing of the insect must be made according to the evidence from all three characters.

Where pubescence is present in the female (except in P.nichoti) the insect may safely be considered a Sphex. In the male, pubescence on the clypeus is useless as a distinction, but it does not seem to occur elsewhere on the body (exceptions?). A series of parallel rugosities on the side of the pronotum in front of the prothoracic lobe, running 
upward and slightly forward, is so nearly universal in Podalonia that it can nearly always be used safely in determining the genus, in connection with the other characters.

These statements indicate why it is difficult to decide whether Sphex and Podalonia should be regarded as distinct genera, only or subgenera.

ANALYTICAL KEY TO SPECIES

1. Females (see p. 7)

Males

2. Anterior margin of clypeus with teeth

Anterior margin of clypeus without teeth

3. Anterior margin of clypeus with four teeth. Large species_........ 4

Anterior margin of clypeus with two teeth

4. Inner face of fore coxa with a tooth near its end: wings usually semi-

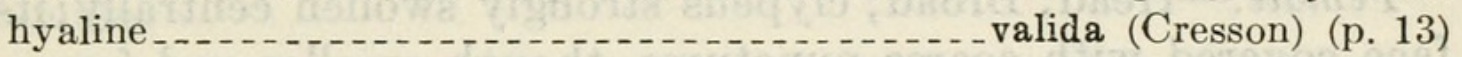

Inner face of fore coxa without a tooth; wings strongly fuliginous.

quadridentata (Cameron) (p. 17)

5. Clypeus silvery white pubescent.

Clypeus without pubescence............... sonorensis (Cameron) (p. 20)

6. Body entirely black (sometimes slightly piceous) ...._luctuosa (Smith) (p. 21)

Head and thorax black; abdomen deep blue _._argentifrons (Cresson) (p. 26)

Head and thorax black; abdomen more or less ferruginous _... . . 7

7. Petiole noticeably longer than hind coxa but shorter than hind coxa and trochanter together.................. violaceipennis (Lepeletier) (p. 30)

Petiole little if any longer than hind coxa; often seemingly shorter violaceipennis, var. compacta, new variety (p. 33)

8. Abdomen partly ferruginous

Abdomen black, sometimes tinged with piceous

9. Legs black _... 10

Legs partly ferruginous _...

10. Inner face of fore coxa with a tooth near its end ... valida (Cresson) (p. 13)

inner face of fore coxa without a tooth near its end

11. Body rather stout for its length.

violaceipennis, var. compacta, new variety (p. 33)

Body slender................ violaceipennis (Lepeletier) (p. 30)

12. Second and third dorsal abdominal plates covered with minute, silvery, decumbent hairs (sericeous) looking like a white, transverse streak.

argentifrons (Cresson) (p. 26)

Without silvery, decumbent hairs on abdomen ...._luctuosa (Smith) (p. 21)

\section{DESCRIPTIONS OF SPECIES}

\section{PODALONIA VALIDA (Cresson)}

Ammophila valida Cresson, Proc. Ent. Soc. Phila., vol. 4, p. 461, $1865 . \quad$ Female. Ammophila grossa Cresson, Trans. Am. Ent. Soc., vol. 4, p. 209, 1872. Female. Ammophila montana Cameron, Biol. Centr.-Amer., Hym., vol. 2, p. 20, 1888. Male.

? Ammophila jason Cameron, Biol. Centr.-Amer., Hym., vol. 2, p. 20, 1888. Female.

Psammophila grossa (Cresson) Melander and Brues, Biol. Bull., vol. 3, p. 41, 1902. Male.

Ammophila (Psammophila) valida (Cresson) Melander, Psyche, vol. 10, pp. 158, $162,1903$. 
Ammophila (Psammophila) grossa (Cresson) Melander, Psyche, vol. 10, p. 158 (female): p. 159 (male) 1903.

Psammophila grossa (Cresson) H. S. Sмгтн, Univ. Neb. Studies, vol. 8, p. 331, 1908. Psammophila valida (Cresson) MiскеL, Univ. Neb. Studies, vol. 17, p. 406, 1917. Psammophila grossa (Cresson) Mickel, Univ. Neb. Studies, vol. 17, p. 406, 1917. Psammophila valida (Cresson) Carter, Ent. News, vol. 34, p. 365, 1924 . Male. Psammophila grossa (Cresson) Carter, Can. Ent., vol. 57, p. 132, 1925 . Female and male.

Psammophila valida (Cresson) CArter, Can. Ent., vol. 57, p. 132, $1925 . \quad$ Female and male.

Head, thorax, petiole (usually), and legs, black; abdomen partly to entirely ferruginous: fore coxa with a small tooth on its inner face near its trochantal articulation. A large species.

Female.-Head: Broad; clypeus strongly swollen centrally; its surface covered with coarse punctures, though smaller and fewer near the middle; its anterior margin rounded and bearing four broad teeth on the middle third, the outer larger and reflexed; vertex rather flat behind ocelli; frons and vertex rather closely punctured except near ocelli; antennae black, the filament more or less brownish sericeous; mandibles tinged with ferruginous over the middle third and sometimes the tip also.

Thorax: Prothorax rather closely punctured like frons, its sides in front of prothoracic lobe obliquely rugose; collar with a slight, median, indented groove toward the mesonotum; mesonotum quite uniformly punctured and with a faint median longitudinal ridge between two indented lines extending about half way back; scutellum with scattered, fine punctures medially; finely, longitudinal rugose elsewhere; postscutellum raised centrally, its sides faintly rugose; propodeal disk coarsely, irregularly rugose, averaging transverse in direction, with a median ridge on front half; more or less punctured between the rugosities; end of propodeum rugose with punctures between; sides rugose and punctured, the rugosities running downward and forward; metapleuron rugose and punctured, the rugosities near the mid-coxa running nearly horizontal; mesopleuron more sparsely rugose, with coarse punctures between the ridges.

Abdomen: Petiole usually black, sometimes partly ferruginous or tinged with ferruginous; straight, longer than hind coxa, its terminal enlargement below the first abdominal dorsal plate more or less ferruginous; first dorsal plate often shaded with black; remaining abdominal plates above and below usually ferruginous, but in specimens from Texas, California (and elsewhere?) the last two segments and sometimes a part of the next one forward may be black and the rest is sometimes darkly clouded.

Wings: Varying from hyaline to somewhat fuliginous; costal vein dark, the others rather light; tegulae black in front, more or less tinged with ferruginous at the lateral and hinder margins. 
Legs. Black, sometimes tinged with ferruginous; fore coxa, near its end on its inner face, with a small tubercle or tooth, often hard to see. On the under surface of trochanter and femur is a row of long hairs and the coxal tooth is nearly (though a little in front of) in the line of this row. Spines of tibia and tarsus, except fore tibia, varying from light to black; claws dark ferruginous; pulvilli well developed.

Male.-Similar to female, except as follows:

Head: Clypeus elongate, silvery pubescent, its anterior margin transverse with rounded corners; frons silvery pubescent.

Thorax: Hairs mixed black and cinerous, some black at base and whitish toward tip; mesopleuron less liable to bear rugosities than in female.

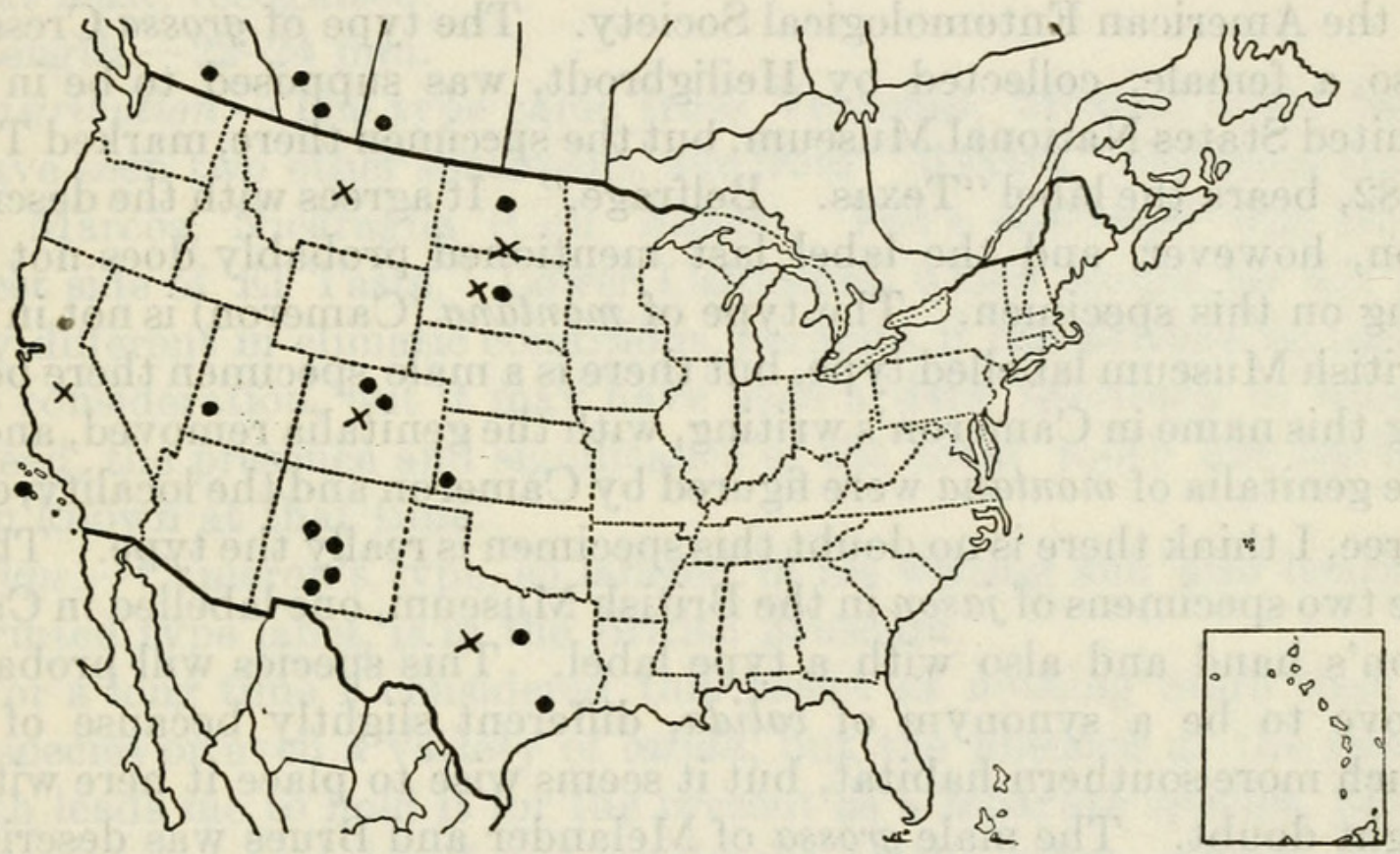

Fig. 1.-Map illustrating the known distribution of Podalonia valida (Cresson)

Abdomen: Terminal segments black in all specimens seen; last ventral plate rather transverse behind, with a broad central emargination though somewhat variable in this regard.

Legs: Cinereous sericeous (coxae often almost pubescent); spines black.

Length.-Females, 18-24 mm; males, $18-22 \mathrm{~mm} ; 44$ females and 32 males examined.

Distribution.-Texas (Bosque, Travis, and Bastrop Counties; Austin, May, 1900); New Mexico (Highrolls, June, 3-12, 1902; Albuquerque; Organ Mountains, August 29; White Mountains, above 6,700 feet, July, 27; Bulah, May 30); Kansas (Morton County, 3,200 feet); Nebraska ("Entire State. Flies from June to September," Smith); Colorado (Denver, September 7, 1901; July 12, 1902; Boulder, September 3; Fort Collins, July 28, 1900); Utah (Beaver Canyon); South Dakota (Pierre); North Dakota (Minot, August 22, 1915, on Kuh- 
nistera oligophylla-O. A. Stevens); Montana; Alberta (Medicine Hat, August 20, 1916; July 17, 1917; Lethbridge, August 18, 1922; August 6, 1923; September 15, 1924; Brooks, July 27, 1923; August 12, 1924) ; British Columbia (Okanogan, July 19, 1915); "N. W. T.”; California (Santa Rosa Island and unnamed places); Mexico.

This insect appears to be most common in arid areas, though extending out of them in Texas and California where the female may have the last abdominal segments black.

One case of abnormal venation has been observed in the specimens studied. This consisted of an incomplete second transverse cubital vein in the fore wing of one side.

Types.- P. valida (Cresson) was described from two female specimens, one of which, now marked Type No. 1929, is in the collection of the American Entomological Society. The type of grossa Cresson, also a female, collected by Heiligbrodt, was supposed to be in the United States National Museum, but the specimen there, marked Type 1682 , bears the label "Texas. Belfrage." It agrees with the description, however, and the label last mentioned probably does not belong on this specimen. The type of montana (Cameron) is not in the British Museum labelled type, but there is a male specimen there bearing this name in Cameron's writing, with the genitalia removed, and as the genitalia of montana were figured by Cameron and the locality, etc., agree, I think there is no doubt this specimen is really the type. There are two specimens of jason in the British Museum, one labelled in Cameron's hand and also with a type label. This species will probably prove to be a synonym of valida, different slightly because of its much more southern habitat, but it seems wise to place it here with a slight doubt. The male grossa of Melander and Brues was described from two specimens taken in Texas, one of which is now in the collection of Prof. A. L. Melander; the location of the other I do not know.

$P$. valida male, described by Carter, is now in the collection of the Canadian National Museum. I have seen all of these types with the exception of those described by Melander and Brues.

There has been some confusion about this species, caused by the idea of early workers that color distribution could be depended on for specific distinction. The first valida had its abdomen entirely ferruginous. In grossa the tip was black and as both were females they were consideredd ifferent species. The males of grossa described by Melander and Brues have black on the abdomen, corresponding with Cresson's female grossa. Carter's valida male is the same and he was perhaps not aware of Melander and Brues' work or thought that, finding no females in Alberta with black on the abdomen, this male could not be grossa but must be the male of valida-in which he was of course correct. 
Ammophila quadridentata Cameron, Biol. Centr.-Amer., Hym., vol. 2, p. 23, 1888. Female.

A mmophila quadridentata (Cameron) Fox, Proc. Cal. Acad. Sci., ser. 2, vol. 4, p. 102, 1894,

A mmophila (Psammophila) quadridentata (Cameron) Melander, Psyche, vol. 10, pp. 158, 162, 1903. Female.

Very similar to valida but with strongly fuliginous wings; a very darkly ferruginous abdomen without black at tip and with no tubercle or tooth on the fore coxa. In one or two cases I have thought that the surface near where this tooth should be was somewhat swollen, but with no actual tooth, long or short, present.

No male which would belong to this species has as yet been found or, at least, recognized.

Length. $-22-24 \mathrm{~mm}$.

Distribution.-The type came from Ventenas, Mexico, 2,000 feet. I have seen two other specimens, one from "Mexico," the other from San Marcos, Nicaragua (Coll. Baker). Fox's specimen was from "west side of El Taste," Lower California, which would be not so very different in climatic conditions, perhaps, if the altitude be taken into consideration, but it may have been a dark specimen of valida instead, the presence and significance of the coxal tooth not having been known at that time.

Type.-Cameron's type, so labeled in his writing and also bearing a printed type label, is in the British Museum.

For a long time I considered this insect as nothing more than a subspecies or even a variety of valida, but the absence of the coxal tooth leads me to hold it for the present as a separate species, often approximated to by suffused specimens of the other, which, however, have the tooth.

\section{PODALONIA NICHOLI (Carter)}

i Ammophila morrisoni Cameron, Biol. Centr.-Amer., Hym., vol. 2, p. 21, 1888. Male.

Psammophila nicholi Carter, Ent. News, vol. 35, p. 366, 1924 . Female.

Head, thorax, petiole and parts of legs black; remainder generally bright red rather than ferruginous; hairs mostly white. A very distinct species.

Female.-Head: Broad; clypeus swollen except marginally, its anterior margin rounded, truncate on central half, with a small tooth at outer end of truncation where the margin begins to curve backward to the base of the mandible; clypeal surface and lower part of frons, particularly at the sides, silvery pubescent and with long hairs which may be almost golden; entire surface of head punctured, though not closely nor very coarsely; antennae black or piceous $30335-27 \dagger-3$ 
near base; black, grayish sericeous outwardly; mandibles varying from entirely black to black with a median ferruginous tinge.

Thorax: Prothorax rather smooth, its sides almost without oblique rugosities in front of the prothoracic lobe; mesonotum minutely, not closely punctured, scutellum with sparse, minute punctures and faint longitudinal rugosities; postscutellum finely, transversely rugose; propodeal disk finely, evenly rugose, the rugosities in front running strongly backward and outward, but on the posterior half, more directly outward; hardly meeting on the middle line they leave a distinct line there, though usually with no ridge; no punctures evident on the disk; end of propodeum with a fovea and a depressed line from tip of disk to the petiolar articulation; at each side of this are oblique rugosities and punctures; sometimes there is a silvery pubescent spot on each side at base of petiole; sides of propodeum irregularly rugose and punctured; metapleuron with rather coarse, oblique punctures and sometimes traces of rugosity; mesopleuron similar.

Abdomen: Petiole almost as long as hind coxa and trochanter together; abdominal segments dark, glistening ferruginous but often tinged darker, appearing to be shaded with black.

Wings: Hyaline, often with a yellowish shade; veins brown; stigma almost yellow.

Legs: Coxae black; the fore coxa with a tooth on its inner face close to the trochantal articulation; trochanters black or more or less ferruginous; femora, tibiae and tarsi ferruginous, often pale; leg hairs and spines pale ferruginous; claws ferruginous; pulvilli well developed.

Male.-Here described for the first time.

Head, thorax, petiole, and parts of the abdomen and legs black; remainder ferruginous; head and thorax quite thickly clothed with long, quite erect, slender, white hairs; wings hyaline with dark veins.

Head: Clypeus extended some distance below the eyes and reflexed forward below a line joining the nearest points of the eyes; central half of its lower margin transverse, slightly, broadly emarginate; its side margins nearly at right angles to the central part; surface densely covered with silvery pubescence; sides of frons similarly pubescent well up toward level of anterior ocellus; a median depressed line from between antennae to anterior ocellus; antennae black or piceous near base, sericeous outwardly; mandibles black or piceous.

Thorax: Pro- and mesonotum rather sparsely punctured, the sides of the former very weakly rugose in front of the prothoracic lobe; thoracic and propodeal markings as in the female; pubescence at base of petiole often absent.

Abdomen: Petiole black, its basal half somewhat punctured and bearing white hairs; about as long as hind coxa and trochanter together; first abdominal segment more or less black above and 
below; last two or three segments black above and below, the extent of the black varying somewhat; last ventral segment rounded acuminate behind, with a broad central notch.

Wings: Hyaline; veins dark brown; tegulae piceous, tinged more or less with ferruginous outwardly.

Legs: Coxae and trochanters black, more or less sericeous; fore coxa with a tooth, as in female; inner portions of femora black, outer portions ferruginous, the proportions varying; tibiae ferruginous, occasionally blackish at the outer end or with a black streak; tarsi piceous, more or less sericeous, the spines and claws light.

There are slight variations in the outline of the clypeal margin and in the amount of ferruginous on the abdomen and legs in specimens of this sex which I have examined.

Length.-Females, 16-18 mm; males, 14-17 mm.

Distribution.-The holotype of this species was taken at Tucson, Ariz., April 5, 1924. I have seen eleven other females, all from Southern California (place not given), ten of these in the collection of the American Entomological Society and one in my own collection. The twelve males seen, also came from Southern California, eleven being in the same lot as the females and one in my own collection. This species should be found in Northwestern Mexico and perhaps New Mexico also, at least.

Types.-The holotype female, which I have studied, is in the Division of Entomology collection of the University of Minnesota, St. Paul. The allotype male (here described) is in the collection of the American Entomological Society at Philadelphia. Two other males used in preparing the description and which may, therefore, be described as paratypes of the allotype, or parallotypes, are also in the collection of the American Entomological Society.

Cameron's species morrisoni was described from a male taken in Northern Sonora, Mexieo. The only specimen in the British Museum, which I could find, labelled "Ammophila morrisoni Cam. Type" in Cameron's writing, is not a male but a female and does not agree at all well with his description. It would seem probable that the label may have been in some way attached to the wrong speeimen, which in 1913 was found with the group of specimens placed under sonorensis, possibly in the belief of whoever placed it there, that the two species are the same.

The type of morrisoni being therefore not available for study, Cameron's description only, remains for comparison with nicholi. It does not agree in all points with the males of nicholi, but is still so similar as to make it not unlikely that the two are the same species. The locality of Cameron's species is not far from where nicholi has been taken. 
This beautiful species, easily distinguished by its bright ferruginous legs, appears to be rare, the lot in Philadelphia having evidently been taken at one time at some place in "So. Cal.," and the only other specimen being the holotype from Tucson. It should be carefully searched for by collectors in those and neighboring regions.

PODALONIA SONORENSIS (Cameron)

Ammophila sonorensis Cameron Biol. Centr.-Amer., Hym., vol. 2, p. 21, 1888.

Female and male.

Ammophila (Psammophila) sonorensis (Cameron) Melander, Psyche, vol. 10, pp. 158, 162, 1903. Female.

Black, except second and parts of first and third dorsal abdominal plates, and more or less of the corresponding ventral ones. Hairs long, black, sometimes with a bluish tinge. Wings quite uniformly fuliginous, the hinder pair less so to beyond the veins, and with a violet reflection. A small species.

Female.-Head: Clypeus broad, only a little more than half as high as wide; its middle swollen; its anterior margin flat and somewhat reflexed laterally and extending downward a short distance, then curving to run transversely to a small tooth, then rather transverse or broadly, weakly emarginate at the middle, this central third between the teeth much less reflexed than the lateral third; surface quite closely and coarsely punctured, bearing long hairs; frons similarly punctured; median impressed line from antennae to anterior ocellus faint; antennae; scape and pedicel shining, black; filament somewhat sericeous, giving a dull olive tinge to these segments; first filament segment not quite twice as long as the second; mandible shining black, with a shade of dark ferruginous near the middle.

Thorax: Collar of pronotum with no perceptible median longitudinal groove above; sides obliquely rugose in front of prothoracic lobe, which is nearly smooth and shining; pronotal surface rather sparsely punctured; mesonotum punctured, perhaps rather more coarsely and closely than pronotum, its anterior half with a median impressed line, double, with a slight ridge between, in front; scutellum rather flat, with a few punctures in front and slightly rugose behind; post-scutellum shining centrally, its sides closely punctured; propodeal disk closely punctured, with more or less of irregular transverse rugosities, most definite and clearest at sides behind the spiracle and at the tip; end of propodeum with a distinct impressed line from tip of disk to petiolar articulation; its surface closely, coarsely punctured; its sides similar except for slight ridges between the punctures; metapleuron similar, except that the ridges may be more evident and tend to run more forward as well as downward; mesopleuron closely punctured, sometimes with traces of rugosities,

Abdomen: Petiole as long as, or slightly longer than, the hind coxa, its enlarged part beneath the first dorsal plate black with a ferrugi- 
nous margin; first dorsal plate black with a ferruginous margin; second, segment ferruginous above and below; third segment ferruginous, mottled or shaded with black, particularly behind; remainder of abdomen black; it is probable that the distribution of ferruginous will vary in different specimens.

Wings: Fore wings fuliginous with violet reflection; hind wings semihyaline basally, somewhat fuliginous beyond the veins; tegulae piceous.

Legs: Black; coxae, trochanters, femora and bases of tibiae with erect hairs; tibiae and tarsi somewhat sericeous, with short, black spines; claws rather ferruginous; no coxal tooth.

Male.-Unknown to me. Cameron says: "The male has the clypeus rounded at the apex, and bears, as does also the face, a sparse silvery pile; and the petiole almost twice the length of the hind coxae." None of these are particularly distinctive features.

Length.-Females, $13-18 \mathrm{~mm}$.

Distribution.-Specimens in the British Museum are marked as from North Sonora, Mexico. I have in my collection a female taken on wild plum blossoms at Placita, New Mexico, 6850 feet, May 5, 1903.

Types.-Cameron evidently had before him both female and male (supposed) of this species. In the British Museum is a female $141 / 2$ $\mathrm{mm}$. long, properly marked for locality and collector, and labeled Type in Cameron's writing, and another with the same locality and collector and with the printed label "B. C. A. Hymen. II. Ammophila sonorensis, Cam.," but without Cameron's label in writing and not marked type. It was probably in the lot studied by Cameron. Of a male, I could find no trace except a mount of genitalia marked as of sonorensis.

This species is apparently far from common. The two specimens in the British Museum and one in my own collection are the only examples met with during an examination of nearly 8,000 specimens of Podalonia. It is easily recognized by the clypeal teeth, the fuliginous wings, and by the shape of the abdomen which is rather globular and rises sharply from the petiole. In fact, superficially, it greatly resembles Chlorion (Priononyx) bifoveolatum (Tashenberg) in the last two features.

PODALONIA LUCTUOSA (F. Smith)

Ammophila luctuosa F. Sмiтн, Cat. Hym. Brit. Mus., vol. 4, p. 224, 1856 . Female.

Ammophila luctuosa (Smith) Cresson, Proc. Ent. Soc. Phila., vol. 4, p. 462, 1865 (part). Female.

Ammophila luctuosa (Smith)? Saussure, Reise d. Novara, Zool., vol. 2, pt. 1, Hym., p. 26, 1867. Female.

?Ammophila mexicana Saussure, Reise d. Novara, Zool., vol. 2, pt. 1, Hym., p. 25, 1867. Female and male. 
?Ammophila piceiventris Cameron, Biol. Centr.-Amer., Hym., vol. 2, p. 22, 1888. Female.

Psammophila luctuosa (Smith) Melander and Broes, Biol. Bull., vol. 3, p. 40, 1902. Female.

Ammophila (Psammophila) luctuosa (Smith) Melander, Psyche, vol. 10, p. 158, 162, 1903. Female.

Psammophila luctuosa (Smith) H. S. Smith, Univ. Neb. Biol. Stud., vol. 8, p. 330, 1908. Female.

Sphex (Psammophila) luctuosa (Smith) Rohwer, Bull. 22, Conn. Geol. \& Nat. Hist. Surv., p. 681., 1916 (part).

Psammophila luctuosa (Smith) Rohwer, Proc. U. S. Nat. Mus., vol. 53, p. 241, 1917.

Psammophila luctuosa (Smith) Mickel, Univ. Neb. Studies, vol., 17, p. 87, 1917. Female.

Psammophila luctuosa (Smith) CARter, Can. Ent., vol. 57, p. 132, 1925 Female, not males.

Jet black, rarely tinged either uniformly or irregularly with brown or piceous; shining; hairs and spines black; claws tinged with ferruginous; wings quite fuliginous, with violet reflection; very variable in size.

Female.-Head: Quite broad; clypeus swollen centrally; its front margin somewhat reflexed except in the middle; rather rounded in outline; its surface somewhat coarsely, closely punctured and bearing long, erect hairs; frons similarly but more closely punctured, as are vertex and cheeks; scape, pedicel and first filament segment of the antennae rather shining, the first often faintly brownish below; the remainder dull; mandible sometimes slightly piceous or chestnut near the middle.

Thorax: pronotum rather high behind, evenly rounded from side to side there, with no median depression or groove; more finely punctured than the head and well clothed with hairs; rugose in front of the prothoracic lobe which is partly smooth and shining; mesonotum quite closely punctured; with a median, longitudinal, depressed line on its anterior half; scutellum rather flatly rounded; punctured, and with traces of rugosities behind; postscutellum dull, finely punctured; propodeal disk rather finely, transverse rugose, closely punctured between the ridges except near its hinder end where the ridges are finer and closer together; end and sides rugose, with rows of punctures between, the rugosities on the sides running rather forward as well as downward; this condition continues forward over the metapleuron onto the mesopleuron, becoming finally a punctured surface only.

Abdomen: Petiole short, straight, hardly longer than hind coxa; abdomen unusually stout, generally very finely sericeous above (fresh specimens); with a few tiny punctures near the hinder margins of the dorsal plates; similar below, but with more punctures; first dorsal 
plate rising very sharply from the petiole, sometimes at a right angle or even less.

Wings: Quite uniformly fuliginous with violet to purple reflection; larger veins dark; smaller ones light brown; tegulae black, sometimes rather piceous, particularly on the margin; shining.

Legs: Rather stout, with scattered, coarse punctures and hairs on coxae, trochanters, femora and near the base of the tibiae; tibiae and tarsi weakly whitish sericeous; tibial and tarsal spines stout; pulvilli absent or very small; claws pale.

Male.-I have seen but one male which I consider as certainly this species. Possibilities as to the male are discussed below.

Very small: Clypeus quite elongate downward, its front margin evenly rounded on its outer third, the central third transverse, even slightly emarginate; surface of clypeus and of frons (particularly $y_{\dot{\alpha}}^{\%}$ at

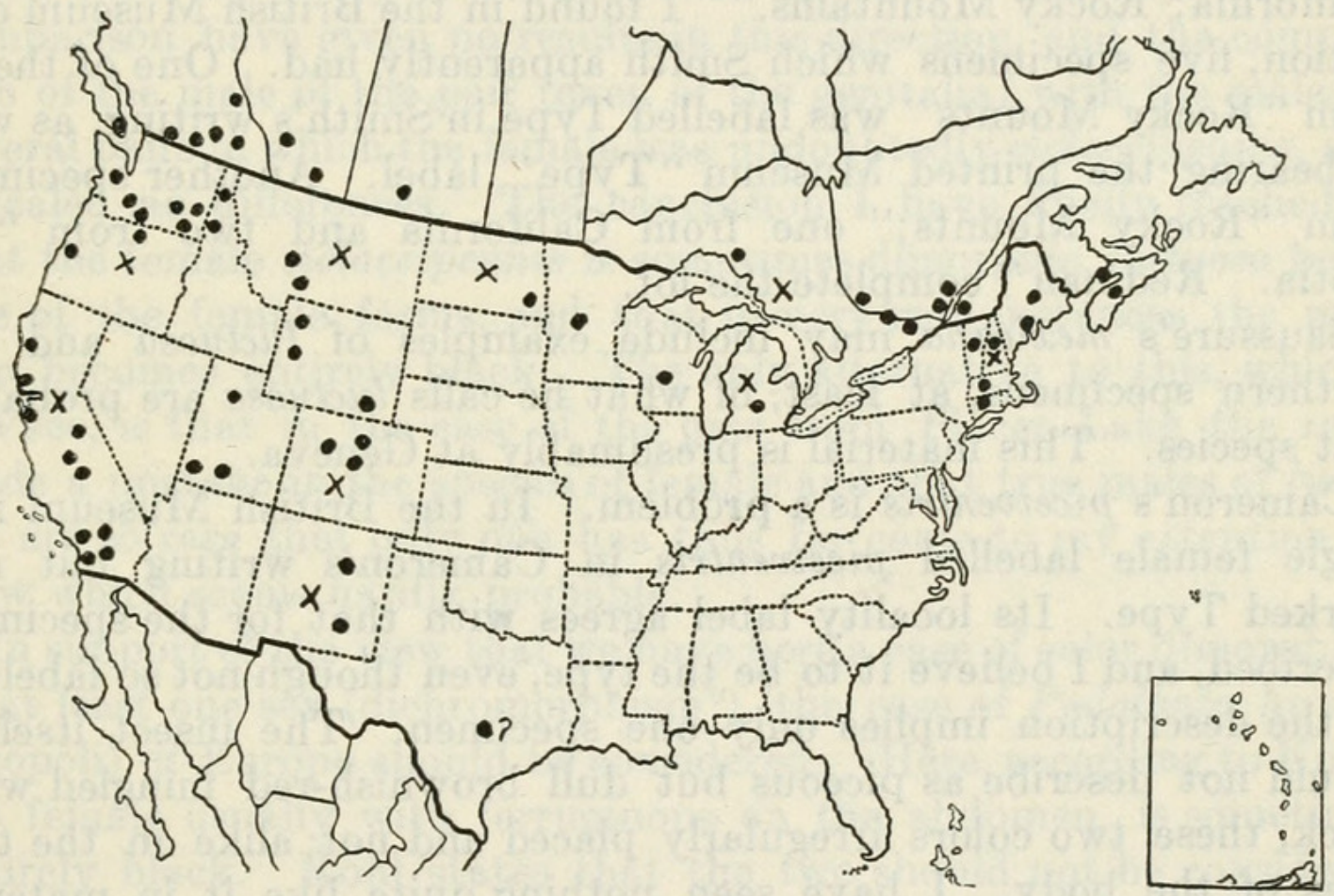

Fig. 2.-Map illustrating the known distribution of Podalonia luctuosa (Smith)

the sides of the latter) silvery pubescent well up toward the ocelli: body rugosities fine (probably because of the small size of the specimen) ; petiole about three-fourths as long as the hind coxa and trochanter together; wings less strongly fuliginous than in the female; legs almost piceous, rather than black; pulvilli large. No trace of ferruginous anywhere.

Length.-Female, $12-20 \mathrm{~mm}$. (one pigmy of $10 \mathrm{~mm}$.); male, 9 $\mathrm{mm}$. (only one seen). Over 350 specimens examined.

Distribution.-Found practically everywhere in the Northern United States and the Southern Canadian territory. I have seen specimens from Nova Scotia and every Province of Canada west to Vancouver; and in the United States from Maine, New Hampshire, Vermont, Massachusetts, Michigan, Wisconsin, Minnesota North Dakota, Montana, Idaho, Washington, Oregon, and California south 
to San Diego County; farther south, from Nebraska (Halsey), Colorado, Utah, Wyoming, New Mexico (Cloudcroft, Las Vegas); one specimen from Texas (Austin), one from Meadow Valley, Mexico, and one marked "Alaska? J. A. Kusche 1916." I feel certain that it is present in Connecticut, New York, Pennsylvania, Ohio, and other States in this belt, but it is a northern species and its extensions southward are in the mountainous districts. I suspect the specimen labelled from Texas is incorrectly marked. Dates of capture vary greatly for different localities but two generations a season would appear probable. The blueberry, Solidago canadensis, Spiraea salicifolia, and Taraxicum taraxicum are plants on which this species has been captured.

Types.-Smith evidently had at least three specimens at hand when he described this species, for he gives, "Hab. Nova Scotia; California; Rocky Mountains." I found in the British Museum collection, five specimens which Smith apparently had. One of these, from "Rocky Mounts" was labelled Type in Smith's writing, as well as bearing the printed Museum "Type" label. Another specimen from "Rocky Mounts;" one from California and two from "N. Scotia. Redman" complete the lot.

Saussure's mexicana may include examples of 7uctuosa and his northern specimens, at least, of what he calls luctuosa are probably that species. This material is presumably at Geneva.

Cameron's piceiventris is a problem. In the British Museum is a single female labelled piceiventris in Cameron's writing but not marked Type. Its locality label agrees with that for the specimen described, and I believe it to be the type, even though not so labeled, as the description implies only one specimen. The insect itself I should not describe as piceous but dull brownish-red mingled with black, these two colors irregularly placed and not alike on the two sides of the body. I have seen nothing quite like it in material studied and am in doubt whether to regard it as a freak (melanistic?) or a good species. The "other examples from Totonicapam, 8,500 to 10,500 feet," I am unable to separate in any way structurally, from luctuosa, but they are more slender. Possibly they represent the condition this species assumes in the southern part of its range. I very much doubt if Cameron was correct in placing them under piceiventris in any case.

The males referred to this species by later writers are undoubtedly those of argentifrons.

The female of luctuosa is ordinarily an easily recognized insect, it being the only one which is black. It is most closely resembled by argentifrons, but this is deep blue, more slender, and the abdomen rises less sharply from the petiole than in luctuosa. 
The male has long been sought for, and following Cresson's guess, many have found it in argentifrons, but the female of this last-named species, sometimes confused with luctuosa ${ }^{6}$ is now known, and argentifrons is therefore eliminated from consideration.

In the United States National Museum collection there is a pair of Podalonias, the neck of the female gripped by the mandibles of the male as in mating. The female is certainly luctuosa, while the male is violaceipennis, having several of the abdominal segments bright ferruginous. The pair was taken in "Sept. Placer Lake Cal." and was in the Riley collection.

This pair has given me much trouble. P.luctuosa, and violaceipennis are both very widely distributed and abont 400 males of violaceipennis were available for study, to find, if possible, whether there were really two extremely similiar species in the lot. Many weeks of comparison have given no results in this direction, and the comparison of the male of the pair (even of the genitalia) with the males of several pairs in which the female was undoubtedly violaceipennis, also revealed no differences. The conclusion I have finally reached is, that the female violaceipennis is sometimes dimorphic, luctuosa being one of the female forms, and that in very rare instances the male also becomes entirely black. The only alternative to this, which I can see, is that in the case of the pair from Placer Lake the male made a mistake in the species of female and that true males of luctuosa are so rare that only one has thus far come to my attention--a view which seems hardly probable.

In support of the view that we have here a case of color dimorphism in at least one sex (dichromorphism?), the case of Podalonia hirsuta (Scopoli) of Europe should be considered. Here, according to Kohl ${ }^{7}$ the female usually with ferruginous on the abdomen, is sometimes entirely black. Kohl states that the two should not be considered separate as there is complete agreement in sculpture and plastic relations, and an almost complete lack of black-bodied males. In Corsica the red-bodied females are almost entirely absent, while one finds no black males of the same. Elsewhere he states that among several hundred males examined, he found only two black-bodied ones.

P. hirsuta is very similar to our violaceipennis in every way and there is even a slight possibility that it may prove to be the same species. In the female the pulvillus is rudimentary or absent. This is true with our luctuosa but not with our female of violaceipennis, so that on this point the comparison fails. On the whole it seems best

- Cresson, Proc. Ent. Soc. Phila., vol. 4, p. 462, 1865, and others.

7 Verh. k. k. zool.-bot. Ges. Wien, vol. 39, p. 21 and p. 275, 1889: Ann. k. k. Naturhist. Mus., Wien, vol. 21, pp. 276-280, 1906. 
to leave luctuosa as a species separate from violaceipennis, for the present, until more pairs have been captured and the evidence they may give becomes available.

Several abnormalities of wing venation have been noted in luctuosa. In one specimen of a left wing a vein stub from the middle of the second transverse cubital runs a short distance into the second cubital cell and a similarly located stub projects outward from the third transverse cubital vein; the right wing is normal. In another specimen a similar stub on the third transverse cubital vein enters the second cubital cell, while the other wing is normal. In another case the left fore wing has a petiolated second transverse cubital vein, but contrary to the condition in Miscus, the stalk is posterior and the small, triangular, extra cell lies against the radial cell between the second and third cubitals; the right wing is normal. One specimen shows the hinder part of the first discoidal cell almost .cut off from the rest by veins from the basal and first recurrent, which run toward each other but do not quite meet. In still another example, the extra vein starts toward the base of the wing from the first recurrent, but soon forks, one fork continuing inward a short distance while the other turns sharply back and joins the discoidal vein near where this and the first recurrent unite, producing a small cell there.

\section{PODALONIA ARGENTIFRONS (Cresson)}

Ammophila argentifrons Cresson, Proc. Ent. Soc. Phila., vol. 4, p. 462, 1865. Male.

?Ammophila mexicana Saussure, Reise d. Novara, Zool., vol. 2, pt. 1, Hym., p 25, 1867. Female and male.

Psammophila argentifrons (Cresson) Melander \& Brues, Biol. Bull., vol. 3. p. 40, 1902.

Ammophila (Psammophila) luctuosa (Smith) Melander, Psyche, vol. 10, pp. 158, 162, $1903 . \quad$ Male.

Psammophila luctuosa (Smith) Mickel, Univ. Neb. Studies, vol. 17, p. 87, 1917. Male in part.

Psammophila luctuosa (Smith) CARter, Can. Ent., vol. 57, p. 132, 1925. Male in part.

Head, thorax, petiole, and legs black: abdomen blue or blue-black, often brilliant, particularly in the female. Hairs black; frequently brown, with the outer part white in the male; wings more or less fuliginous, least so in the male.

Female.-Here first described, unless mexicana Saussure should prove to be this species.

Head: Considerably broader than thorax; clypeus broad, somewhat swollen, its front margin quite transverse, caused largely by a broad, somewhat reflexed, smooth surfaced downward extension from near the middle nearly out to the eyes, thus different from luctuosa where the margin is more rounded; surface rather sparsely, coarsely 
punctured and with stout hairs; frons more finely punctured and with finer hairs; one markedly larger puncture behind each lateral ocellus nearly in line with this and the median ocellus; inner margins of compound eyes slightly nearer above than below (always?); antennal scape, pedicel and first segment of filament shining, remainder dull; mandibles shining black but with a ferruginous tinge near the middle, varying in strength in different specimens.

Thorax: Prothorax rather sparsely punctured, its sides in front of the prothoracic lobe strongly rugose; the top of the collar in front of the mesonotum rounded laterally but tending toward a higher median portion with a slight depression on each side rather than an even curve; mesonotum sparsely punctured, with distinct median anterior groove; scutellum smooth in front except for a few punctures; slightly rugose behind; postscutellum with a central, oblong-oval area raised above the rest of the plate which is confused in markings, and dull; propodeal disk dull, its surface covered by irregularly transverse ridges, often connected, and with punctures between, and bearing long hairs; end and sides similar except that at the sides of the petiole the ridges are vertical, parallel, and more distinct; near the propodeometapleural suture the ridges are not evident; metapleuron dull, covered by somewhat irregular but approximately vertical ridges (sides of propodeum, the meso- and metapleura vary in amount of rugosity in different specimens); mesopleuron irregularly, coarsely punctured, more or less rugose.

Abdomen: Petiole short, stout, straight, only slightly longer than hind coxa, its enlarged end under the first dorsal plate, black; first dorsal plate rising quite sharply from the petiole, but less so than in luctuosa; this plate and the rest of the abdomen a rich, deep, rather shining blue-almost navy blue-with scattered, minute punctures most abundant toward the hinder margin of each plate; last plate more uniformly punctured and bearing larger hairs.

Wings: Quite strongly fuliginous with a violet reflection, the hind pair the least, but strongly so beyond the veins; veins piceous to black; tegulae black, sometimes slightly piceous.

Legs: Black, sometimes tinged with piceous to brown; spines of the color of the leg segments to which they are attached; fore-tarsal comb-spines long, of nearly equal diameter from base to tip, the other spines more slender and pointed; claws pale brown; pulvilli moderately developed.

Male.-Body more slender than in the female. Clypeus and frons, to insertion of antennae in the middle and well up toward top of the eyes at the sides, densely silvery pubescent, the hairs forming this being unusually fine and closely decumbent; anterior margin a considerable distance below the eyes, its outer third rounded, its middle transverse, very slightly emarginated. 
Thoracic hairs varying from entirely black to black or brown with their outer ends, or more, white.

Petiole almost as long as hind coxa and trochanter together, slightly arched downward on its outer two-thirds; abdomen blue; surface of second and third dorsal plates, particularly near the middle line, more or less covered by very minute, decumbent, white hairs (whitish sericeous) which may also be present to some extent on the plates next in front and behind (in badly worn specimens this may be worn off and it is always better seen from some angles than others); hinder end of last ventral plate slightly truncate; the last three ventral plates are less distinctly blue than the others, and sometimes a brownish tinge may be seen here or there on the abdomen. Rarely, the first and second dorsal abdominal plates have a reddish tinge as though they were trying to become ferruginous.

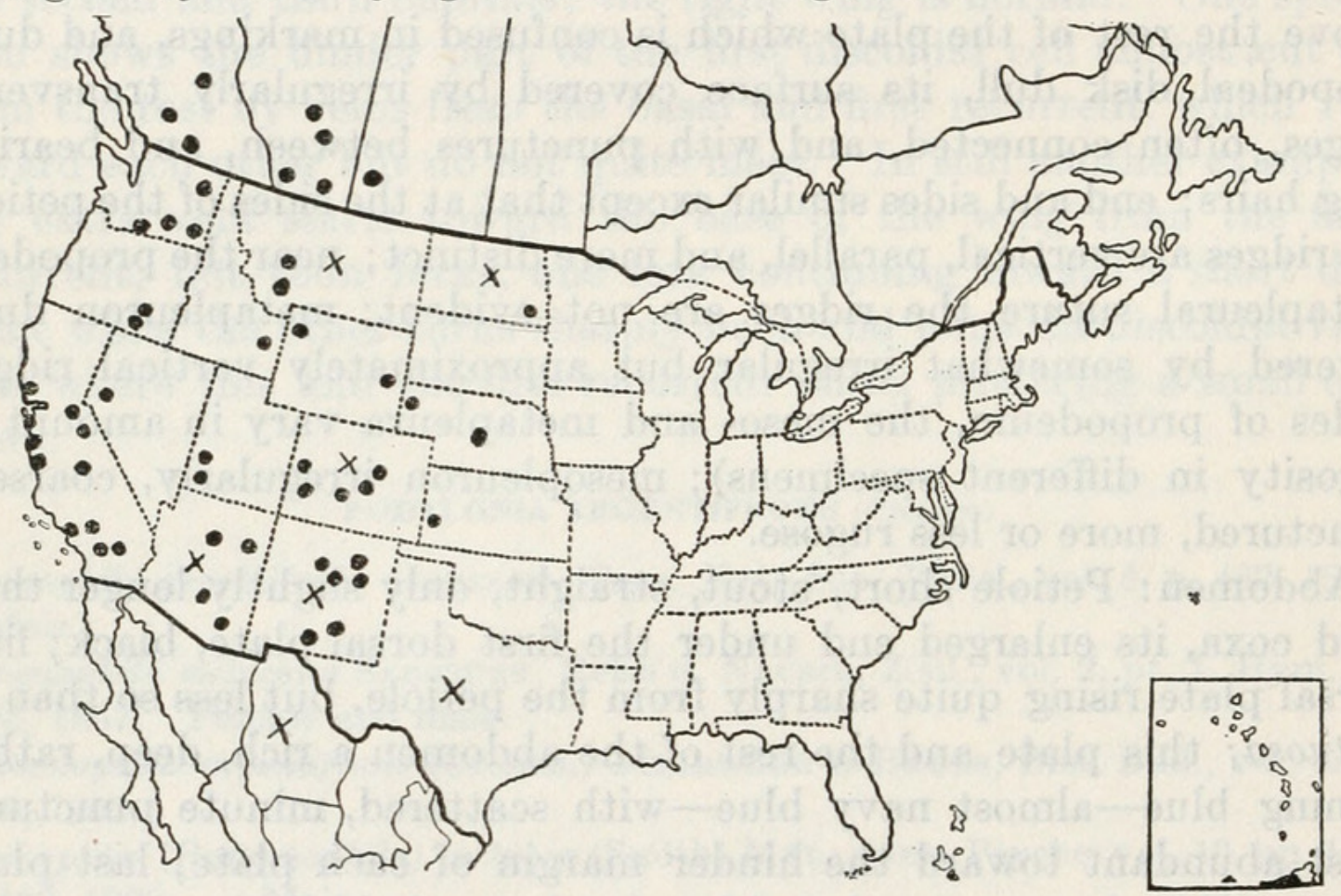

Fig. 3.-Map illustrating the known distribution Podalonia argentifrons (Cresson)

Tegulae black, sometimes with a brownish tinge, and sometimes with a trace of whitish sericeous.

Legs more or less whitish sericeous outwardly.

Length.-Females, 12-17 mm.; males, 11-16 mm. (one male 9 $\mathrm{mm}$.). One hundred and forty-three specimens studied.

Distribution.-I have seen specimens marked "Texas, Belfrage" which would imply central Texas; Kansas (Hamilton County); Nebraska (Ashland, Harrison, etc.); North Dakota (Sheldon and Bowman); Wyoming (Jackson); Montana (Helena and Elkhorn Mountains); Alberta (several localities); British Columbia (Chilcotin, Keremer, and Nicola); Idaho (Rexburg); Washington (Eastern Ritzville, Pullman, and Colville); Oregon (Harney County and Burns); Colorado (many places); Utah (Iron and Beaver Counties); Nevada (Ormsby County); California (general); New Mexico and 
Arizona (general). Dates of capture make it appear probable that this species has two generations a year in the southern and one in the northern part of its range.

Types.-Cresson described the male from 20 specimens, one of which he selected later as the type. This is now in the collection of the American Entomological Society. At one time several of the specimens bore a printed "Type" label and these at least should have the rank of paratypes. I saw the collection before the new rating, just indicated, was made and it is my recollection that only four or five bore the Type label and therefore the remainder would rank only as other specimens present in the collection at the time the description was written. Cresson, following his description, made the unfortunate remark: "May be the male of A. luctuosa Smith." This has been accepted by several workers as correct, and has led to confusion of the two species to some extent.

Saussure's type, or types, of mexicana I have not seen. They are probably at Geneva. The words "abdomine coeruleo" are very suggestive of the female argentifrons, but I hesitate to declare mexicana a synonym, and leave it to some one who can see Saussure's specimens to settle this point. Melander ${ }^{8}$ accepted Cresson's idea that this insect is the male of luctuosa as correct, and so sunk Cresson's name as a synonym, and Mickel did the same. I have seen some of the male specimens named luctuosa by Carter $^{9}$ and they are argentifrons.

The descriptions here given of both sexes are from a pair in the collection of the California Academy of Sciences, taken by E. P. Van Duzee, on March 9, 1916, "along the edges of the sand dunes just inside the seashore line about a mile south of the Cliff House and near the radio station, San Francisco," ${ }^{10}$ modified only enough to include certain variations seen in other specimens. The female of this pair is therefore the allotype female of argentifrons, unless mexicana Saussure proves to be the same. It will be found in the collection of the California Academy of Sciences.

The female of this species has puzzled students of the group from the time when the male was first described. Conclusive evidence on this was first obtained when, in 1918, I found in the collection of the California Academy of Sciences at San Francisco two pairs, on two pins, of these insects, the male in both cases being argentifrons and the female not luctuosa but an insect hitherto undescribed by any American entomologist. The loan of these specimens has enabled me to prepare the above descriptions of the female and male from a known pair. 
The other pair referred to, in the collection of the Academy, showed three specimens of this same species, two males and a female, and was labeled: "Pyramid Pk. at 8,000 ft., El Dorado Co., Cal., VIII, 15, 1902. Coll. by E. C. Van Dyke." Correspondence with Doctor Van Dyke about this capture has produced the following statement from him: "I remember * * * capturing the three specimens, killing them in a separate bottle, and mounting them as noted by you. It was my belief at the time that a male had pounced upon a female and was in the act of mating when a rival pounced upon him and attempted to replace him. Sphecidae caught in the act of mating are none too common so I made an effort to preserve this trio so as to enable whoever worked up my catch to be given as much aid as possible * * * It has been my habit when collecting Coleoptera to mount pairs upon the same pin whenever they were at all different and in my miscellaneous collecting I have simply carried out the same idea."

Four specimens of those which have come under my observation have abnormal venation, three males and a female. In the female a vein stub from the middle of the second transverse cubital enters the second cubital cell for a short distance, in both wings. In a male from Colorado the second transverse cubital vein in one wing is incomplete and with a cross bar anteriorly, while in the other it has a sharp central bend into the second cubital cell. A California male has an incomplete second transverse cubital running back and out, but not reaching the cubital vein, in both wings. A small male, without data, has three cubital cells on one side, the third barrelshaped as in pacifica Melander and Brues, on one side, while on the other side the second transverse cubital is entirely absent, giving the venation of Coleoptera.

One male has been found stylopized.

\section{PODALONIA VIOLACEIPENNIS (Lepeletier)}

Ammophila violaceipennis Lepeletier, Hist. Nat. Ins. Hym., vol. 3, p. 370, 1845. Female.

Ammophila atriceps Sмгтн, Cat. Hym. Brit. Mus., vol. 4, p. 221, 1856. Female and male.

Ammophila cementaria Sмгтн, Cat. Hym. Brit. Mus., vol. 4, p. 223, 1856. Female. Ammophila robusta Cresson, Proc. Ent. Soc. Phila., vol. 4, p. 461, 1865 . Female. Ammophila communis Cresson, Proc. Ent. Soc. Phila., vol. 4, p. 462, 1865. Male. Ammophila alpestris Cameron, Biol. Centr.-Am., Hym., vol. 2, p. 21, 1888. Male. Psammophila violaceipennis (Lepeletier) Melander and Brues, Biol. Bull., vol. 3 , p. 41, 1902.

Psammophila pacifica Melander and Brues, Biol. Bull., vol. 3, p. 42, 1902, Male.

Ammophila (Psammophila) violaceipennis (Lepeletier) Melander, Psyche, vol. 10, pp. 156, 159, 162, 1903.

Psammophila violaceipennis (Lepeletier) H. S. Sмгтн, Univ. Neb. Studies, vol. 8, p. 8, 1908. Female. 
Sphex (Psammophila) violaceipennis (Lepeletier) Rohwer, Bull. 22, Conn. Geol.

$\&$ Nat. Hist. Surv., p. $681,1916$.

Psammophila violaceipennis (Lepeletier) Rohwer, Proc. U. S. Nat. Mus., vol. 53, p. 241, 1917.

Psammophila violaceipennis (Lepeletier) Mickel, Univ. Neb. Studies, vol. 17, p. 88, 1917.

Psammophila violaceipennis (Lepeletier) CARter, Can. Ent., vol. 57, p. 132, 1925.

Head, thorax, and legs black; abdomen ferruginous and black in varying proportions; wings semihyaline to quite fuliginous; rather slender insects for their length; hairs varying from all black (females generally and some males) to nearly all white, with all gradations between these extremes.

Female.-Hairs on head and body usually black; sometimes white or white-tipped on hinder end of thoracic mass, this condition extending forward different distances in different specimens.

Head: Broad; clypeus swollen centrally; its front margin broadly curved, the outer third reflexed and smooth, its center very slightly emarginate; surface coarsely, quite closely punctured; frons similarly punctured; with an evident, median, depressed line from antennal insertions to median ocellus; antennae black; filament rather brownish sericeous; second filament segment varying from a little over half to nine-tenths the length of the first; mandibles black to piceous; more or less tinged with ferruginous near the middle.

Thorax: Pronotum rather less closely and coarsely punctured than the frons; rugose in front of the prothoracic lobe which is nearly smooth; mesonotum similarly punctured; with an evident, median, depressed line on its front half; scutellum punctured and also slightly rugose; postscutellum with a rather high, transverse ridge centrally; propodeal disk coarsely punctured; with irregular rugosities, becoming rather more regular and transverse behind (quite variable in different examples); its end, near the petiole, and its sides with weak, nearly vertical rugosities; metapleuron rather more sparsely punctured, the punctures tending to lie in nearly vertical rows, producing almost a weakly rugose appearance; mesopleuron rather sparsely and coarsely punctured.

Abdomen: Petiole black; from 68 to 89 hundredths the length of hind coxa and trochanter together (very variable and unreliable as a distinctive character; see Measurements, page 6); abdominal mass ferruginous and black, varying in distribution from ferruginous on posterior margin of first dorsal plate and petiolar expansion beneath, and the second segment, to ferruginous for the entire abdominal mass, though darkened at tip; tip of abdomen with scattered, minute punctures, particularly below.

Wings: More or less fuliginous, particularly beyond the veins; with a violet tinge; veins dark; tegulae varying from black, through black with light margin to entirely pale. 
Legs: Black; femora, tibiae, and tarsi whitish sericeous, at least in fresh specimens; spines black; stout; claws and outer tarsal segments tending toward ferruginous; tarsal spines all stout, those of the fore legs long and often holding their basal diameter well out toward the tip; pulvilli well developed.

Male.-Hairs usually black on the head; white, black, or brown, tipped with white, or mixed, elsewhere. White hairs appear first near the hinder end of the thoracic mass and extend forward, first along the sides, later dorsally, until they may cover the entire thorax and even influence those on the head. The first step in the change of color appears to be that the tip becomes white while the basal half remains dark. Clypeal hairs sometimes white.

Head: Clypeus and frons (well up at the sides) silvery pubescent; anterior margin of clypeus considerably below the bottom of the eyes; its margin transverse (sometimes a little rounded), often with a very slight, median emargination; second filament segment of antenna averaging more than three-fourths the length of the first, but quite variable; mandibles black, sometimes faintly tinged with ferruginous in the middle.

Thorax: Scutellum faintly, longitudinally rugose behind; propodeal disk dull black; closely punctured; with more or less evident transverse rugosities behind.

Abdomen: Petiole from slightly shorter to slightly longer than hind coxa and trochanter together; part of the first abdominal dorsal plate and of the petiolar expansion beneath it, with the second segment at least, usually ferruginous, but this may increase to include nearly all of the first dorsal plate and the petiolar expansion in front, and as far backward, in extreme cases, as to affect the seventh segment somewhat (in cases of backward extension of the ferruginous, parts of segments involved may show streaks, spots, or shades of dark; the ventral plate or the sides may be partly or entirely ferruginous, while the dorsal middle is black or dark, or vice versa); terminal ventral plate rounded at the sides, truncate at the end, with a slight, broad emargination.

Wings: Generally less deeply fuliginous than in the female; veins dark. In specimens from arid regions these may be lighter, even almost honey-yellow.

Legs: Tibiae and tarsi whitish sericeous; outer tarsal segments tending, sometimes quite strongly, toward ferruginous.

Length.-Females, 12-21 mm.; males, 10.5-20 mm. Five hundred and fifty nine examples studied; many others examined less carefully. The males appear to be far more abundant than the females, the division in this number being: Males, 397; females, 162. This may, of itself, have some bearing on the possibility that luctuosa is a female form of this species. 
Variation.-A series of specimens from Sausalito, Calif., and single examples from New Mexico and elsewhere show slight differences from the more usual form of violaceipennis and for a time I considered them representatives of a closely related but undescribed species. In these specimens the females are shorter and stouter; have a petiole no longer, and sometimes even shorter, than the hind coxa; the lateral third of the margin of the clypeus and the side of this plate near the eye, nearly half way up to the antennal insertion, are smooth; the mandible has pronounced ferruginous color in its middle and the under side of the antennal scape is tinged with ferruginous.

In the male (one specimen from the Sausalito lot) it is almost impossible to find any difference from the usual male violaceipennis except that it is shorter and stouter.

Examination of a long series of specimens has failed to separate these entirely from the usual form, however. There are varying degrees of stoutness; intermediate conditions on the clypeus between close punctures and none, on the areas above indicated; gradations from mandibles entirely black to those strongly ferruginous in the middle, and variations in color on the under side of the scape, from black all the way to the ferruginous tinge, together with great variations in the length of the petiole compared with that of the hind femur and trochanter. Beginning with the extreme forms and arranging specimens in a series, from these toward the typical form of the species, shows that Cresson's robusta, in structure and proportions, stands about in the middle of the row, at the other end of which is the typical violaceipennis. Whether this will justify varietal names is open to question but, if at all, the extreme condition at least should be indicated, and specimens of this type may be termed variety compacta. Specimens of this extreme degree of variation have therefore been designated as follows: Holotype female from Sausalito, California; allotype male from Sausalito, California; paratype female from "Mt. Shasta dist. Cal." in the collection of the American Museum of Natural History, New York; two paratype females from "Cal." in the collection of the American Entomological Society at Philadelphia; one paratype female from "Cave Spg., N.M., Albert" in the collection of the United States National Museum.

Distribution.-Generally distributed over the southern portions of Canada from Nova Scotia to Vancouver Island, with one specimen from Fort McLeod, British Columbia (about latitude $55^{\circ}$ ), and throughout the Northern United States from Maine to Washington. Farther south I have seen specimens to Pennsylvania; then from North Carolina and Florida. Westward it has been taken in Indiana, Illinois, Kansas, Nebraska, Colorado, Nevada, Oregon, and California. In the more southerly localities I have seen examples from New 
Mexico, Arizona, Mexico (Meadow Valley) and elsewhere, and Costa Rica. In Kansas it has been taken on Melilotus alba; in North Dakota on Erigeron philadelphicus and Cleome serrulata, and in Montana on alfalfa flowers. A specimen from Colorado has on the pin with it a naked larva (probably of a Noctuid) about $27 \mathrm{~mm}$. long, and specimens have been reared by C. N. Ainslee, in Utah, from cutworms.

Types.-Lepeletier's type of violaceipennis was in the Serville collection and its locality is given as "Philadelphie." I have been

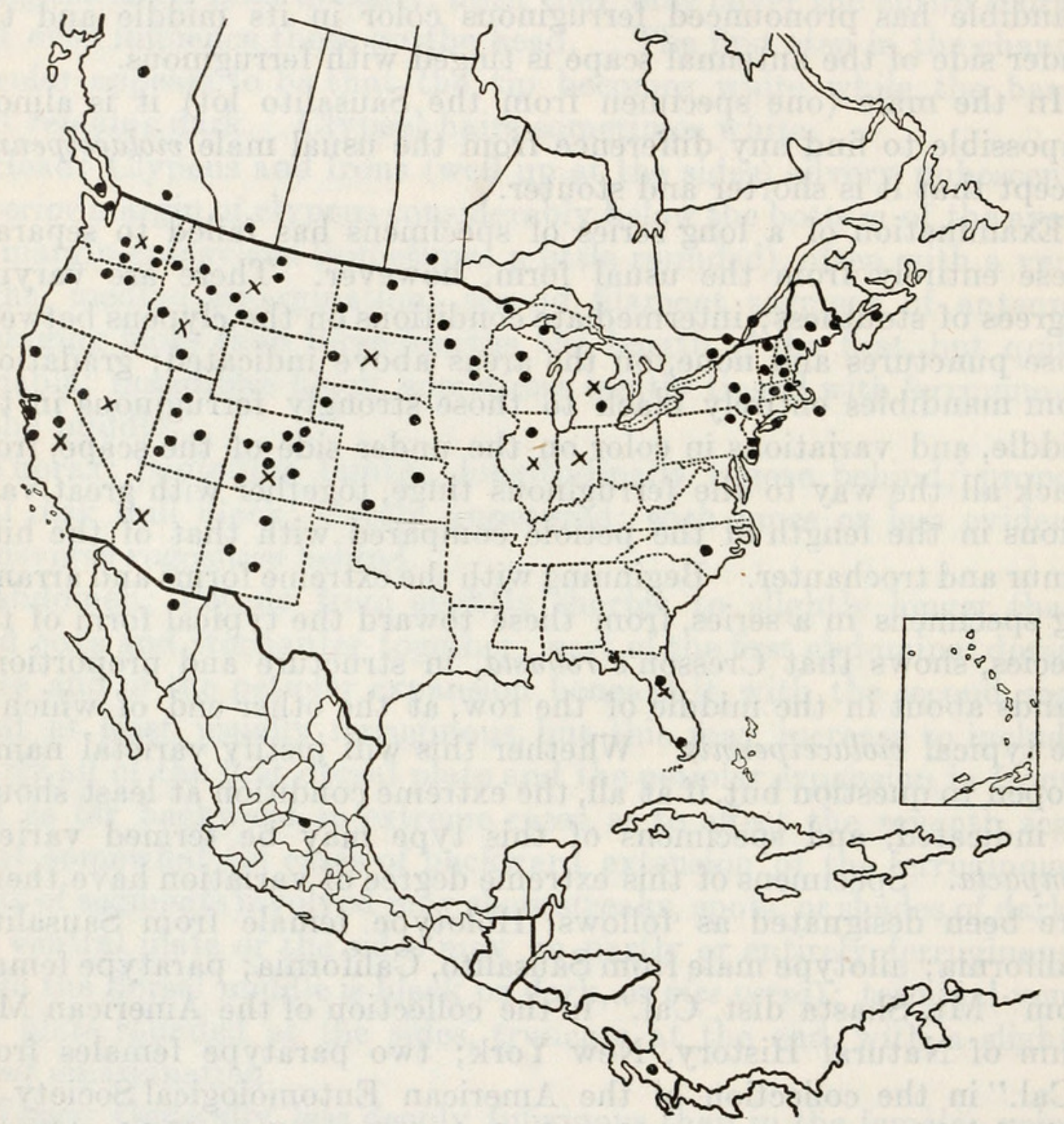

Fig 4.-Map illustrating the known distribution of Podalonia violaceipennis (Lepeletier)

unable to find this insect though I made a long search for it at the Muséum d' Histoire naturelle at Paris, nor any material of the Serville collection. What has become of this collection I have been unable to learn. I am entirely in agreement with Melander, however, that the insect described above is that species.

There are three specimens in the British Museum which should be considered in connection with Smith's atriceps. Smith described this species, female and male, from Mexico. One of the three specimens bears a circular label marked " 43 " above " 14 " on one side, and 
"Mexico" on the other; and an oblong label on blue paper, marked "atriceps Sm." in Smith's writing. Each of the other two bears a circular label with numbers on one side and "California" on the other. These must be thrown out of consideration as types, not being from the proper locality. As all three are males, Smith's female type is apparently lost, and the male first mentioned above may not be the original type specimen. It is authoritatively marked as atriceps by Smith himself, however, and is from the proper locality, and may therefore be considered an authentic specimen for comparison. It is the same as violaceipennis as here recognized and described.

Smith described cementaria from a female, or females, the only clue to the number he examined being the localities he lists, which are: "St. John's Bluff, East Florida; Georgia." There are six specimens in the British Museum which Smith evidently studied at one time or another, but as two of these are marked "N. America," and the third has no locality label, these can not be the types. These three are also marked "Smith coll. pres. by Mrs. Farren White 99303." It is on record that Smith's first set of exotic Hymenoptera went to the British Museum and the remainder went to Mr. Farren White and after his death went to the Museum. This leaves three specimens for consideration as type of this species. All are females and the female only, was described. Of the three, one is labelled (1) “Type;" (2) "E. Doubleday. St. John's Bluff E. Florida” printed; (3) "Ammophila cementaria Smith (Type)" in Smith's writing; (4) “F. Sm. Coll. Type 79.22." Another is labelled (1) "Type;" (2) "35 Harris's lab. 496 E. Doubleday St. John's Bluff E. Florida;" (3) "cementaria Smith Georgia," apparently in Smith's writing; (4) "F. Smith Coll. Type 79.22." The third is marked (1) "Georgia," a printed label; (2) "Ammophila cementaria Smith Cotype," apparently in Smith's writing; (3) "cementaria Smith Georgia" also apparently written by Smith; (4) "F. Smith Coll. Type 79.22." This last label, borne by all three, I am informed was put on each pin when the Smith collection was acquired by the Museum and that the word "Type" was written on by Kirby. This would remove these labels from primary consideration in selecting the type specimens, and the "Type" label on the first two is the regular Museum label, not put on by Smith. The second specimen is credited both to East Florida and to Georgia, raising a doubt as to the reliability of one of the labels. Label No. 3 on the first specimen above is marked Type, in parenthesis, which was not Smith's usual practice, at least as is shown by numerous other labels of his in the Museum. Was it added by someone else later? Label 2 on the third specimen bears the word "cotype." This is the only case of the use of this word by Smith, which I have met with. Did he write it or was it added later? 
The only conclusions I can reach as to the standing of these specimens are that they were all probably in Smith's hands at the time he described the species, and that the third is probably the Georgia specimen. Of the other two, the second has the reliability of its labels affected by the contradictory locality statements, and I am of the opinion that as between the three, the first should be considered the type (Lectotype) and the third, the Georgia specimen mentioned in connection with this description. These specimens are undoubtedly violaceipennis as here interpreted.

Cresson described robusta from eight female specimens. At first several of these bore printed "Type" labels but later he designated one as the type, which would leave the others as probably of paratype rating. The type, and several of the other specimens at least, are in the collection of the American Entomological Society where I have studied them. It is violaceipennis, but from arid or semiarid regions, with a correspondingly greater area of ferruginous than in eastern specimens.

To the species communis, described by Cresson from 40 male specimens, the statements made for robusta apply equally well. It is the average arid or semiarid region coloration of the male violaceipennis.

Of Ammophila alpestris Cameron I found five specimens in the British Museum marked as belonging to the Biologia collections, one of them labeled "Ammophila alpestris Cam. Type" in Cameron's writing and from the locality given with his description. It is undoubtedly the type, though the length measurements he gives show that he consulted the other specimens. It is an arid region male violaceipennis, being rather extreme in that even the long hairs on the front of the head are white. I was unable to make the third antennal segment (first filament) one-half longer than the fourth, as stated by Cameron, but it is well within the range of variation found in violaceipennis.

Psammophila pacifica Melander and Brues was described from one male specimen collected at Pacific Grove, California, based on a peculiarly shaped third cubital cell, strongly convergent eyes, white pubescence, and very slender form. The third cubital cell is unusual in form, being barrel shaped, but I have seen specimens similar to this on one wing and quite normal on the other. The white pubesence, if by this the close, decumbent pubescence on the face, is meant, is normal to all male Podalonias, but if it is the long hairs which is meant, as is more probable, considering the rest of the description, I am totally unable to find them on the type, the long hairs on the head being black. The eyes are no more convergent than is often the case in males, this being a usual sexual feature. I am unable to consider this specimen as other than a small example of male violaceipennis with a third cubital cell of rather unusual form. 
This very widely distributed insect has been perhaps the greatest sufferer in the genus, from the belief of the older workers on Sphecids, both in this country and in Europe, that color area was a reliable means of distinguishing species. The result was that a specimen with two ferruginous abdominal segments was considered different from one having three, four, or more of that color. Variation in the color of the hairs and the place where they ceased to be white and became black has also caused trouble, and other varying characters have also contributed to the confusion.

For more than three years I labored to find some reliable separation of the species here listed as synonyms of violaceipennis, studying long series of specimens again and again, and even making mounts of the genitalia and last ventral abdominal plate, but without success. Finally I arranged the material geographically and at once order began to come out of chaos, a series of beautiful gradations developing, closely paralleled by humidity conditions in different regions. A similar study in the genus $S p h e x^{11}$ gave exactly similar results, and, in the same way, the various species listed under the bibliography of violaceipennis all fell into line.

Abnormal venation in this species is sometimes met with. In one specimen seen the left fore wing has the second transverse cubital vein forked in its anterior half, forming an extra, triangular cell against the radial cell, and in that region separating the second and third cubital cells. The fore wing of the other side is normal. More or less barrel shaped third cubital cells are sometimes met with, and various other abnormalities occasionally occur.

\section{SPECIES OF UNCERTAIN POSITION}

PODALONIA JASON (Cameron)

Ammophilajason Cameron, Biol. Centr.-Amer., Hym., vol. 2, p. 20, 1888. Female.

A study of Cameron's type gives the following facts: Clypeal margin rounded, with four slight, rounded projections located about where the teeth are in valida but not like teeth. Possibly the teeth might wear down to this condition. Antennal scape shining, almost piceous; third antennal segment one-third longer than the fourth (not "more than twice the length of the fourth" as Cameron writes). The wings are more fuliginous than in average specimens of valida but this specimen is from Guatemala and quadridentata is an evidence how a related form from the South is dark; the markings on the propodeal shield differ somewhat from those in typical valida but are well within the limits of variation of this part; the legs are not sericeous but this is liable to wear off in old specimens and the clypeal teeth suggest that this may have been the case. 
PODALONIA MEXICANA (Saussure)

Ammophila mexicana Saussure, Reise d. Novara, Zool., vol. 2, pt. 1, Hym., p. 25, 1867. Female and male.

I have not seen Saussure's types of this species. So far as the description goes I can find no statements which would prevent this from being argentifrons Cresson.

The original description is as follows:

"Nigra, nigro-hirta, abdomine coeruleo, alis pallide fumatis, cyanescentibus.-Long. corp. 0.016; alae 0.011 .

q Nigra, breviter nigro-vel cinereo-hirta. Clypeus et mesonotum crasse, caput et prothorax tenuius punctata. Pronotum medium postice et mesonotum antice sulco divisa. Mesonotum supra et scutellum nitida, sparse punctata. Postscutellum tuberculo instructum. Metanotum transversim striatum et rugosum, supra utrinque sulcatum et in medio obsolete sulco tenui divisum, lateribus sulco obliquo valde notatis. Abdomen coeruleum; petiolo subbrevi, paulo magis quam dimidium primi segmenti efficiente. Alae fumatae, violaceo-micantes; tertia areola cubitalis extus rotundata (scilicet antice et postice coarctata).

$\checkmark$ Minor, gracilis; clypei apice truncato, margine subconcavo et utrinque rotundato clypeo et facie capitis valde argentatis.

Variat.: $a$ Alis subhyalinis, margine apicali griseo-cyanescente.- $b$ Alis plus minusve obscurioribus.

In agRo meXICANo frequens; in Cordilleris orientalibus (Cordoba, Sangolica) et etiam in campis altioribus et frigidioribus (Teshuitlan, et in valle urbis Mexico) specimina numerosa cepi."

PODALONIA MORRISONI (Cameron)

Ammophila morrisoni Cameron, Biol. Centr.-Amer., Hym., vol. 2, p. 21, 1888. Male.

The only specimen I could find in the British Museum is labeled "Ammophila morrisoni Cam. Type" in Cameron's writing, but is a female though Cameron figures the genitalia of the male and describes it as a male. Someone has placed this insect under sonorensis in the collection. The description says: "The long, silvery-white hair is long, moderately dense, and almost uniformly distributed." The specimen above referred to has no white hairs. Cameron gives the length as $21 \mathrm{~mm}$., while this specimen is $14 \mathrm{~mm}$. Cameron says that there is no central mesonotal furrow, while this specimen has one. In other regards also, this insect does not agree with the description and I am of the opinion that his label has, in some way, gotten onto the wrong specimen. I did not see anywhere in the collection an insect whirh did seem to meet the description of this species.

In many ways Cameron's description seems to agree with the male of nicholi Carter and this may prove to be a synonym. Until more evidence on this point can be obtained, however, the two may well be kept separate. 


\section{PODAlONia PICEIVENTRIS (Cameron)}

Ammophila piceiventris Cameron, Biol. Centr.-Amer., Hym., vol. 2, p. 22, 1888. Female and variety.

One female in the British Museum bears Cameron's written label "Ammophila piceiventris Cam." but without the word "Type," and the locality label is that given for the type. The description reads as though prepared from a single specimen and I consider the example as probably the type, even though it is not so labeled.

I have seen nothing quite like this specimen, in coloration, elsewhere. Cameron's description uses the word piceous, but to me the color is nearer a brownish-red. This is evident on the petiole, abdomen, legs, clypeus, frons, vertex, cheeks, and all plates on the sides, but everywhere mingled with black (almost mottled).

Structurally it is very similar to luctuosa though more slender. The clypeal margin somewhat resembles that of sonorensis, but is without teeth, and the hairs, like sonorensis, have a bluish color at some angles.

I can not place this insect with any of those treated in this article, and consider it either as a good species or a color freak, either of luctuosa (which I greatly doubt) or of violaceipennis.

The varieties mentioned by Cameron are, in my opinion, southern examples of luctuosa. Structurally and in color they agree with this species and the only difference I can see is that the specimens are somewhat more slender. 


\section{EXPLANATION OF PLATES}

These drawings were made from enlarged photographs on which the lines desired were traced, the picture then erased, and the line drawings thus produced were again enlarged by photography. This explains a slight lack of symmetry, in some of the figures, due to difficulty in getting the insect exactly posed.

\section{Plate 1}

FIg. 1. Side view of Podalonia valida (Cresson). $\quad c-$ - collar of prothorax; $e$-eye; $l m$-levator muscle; $m n$-mesonotum; $m s c$-mesocoxa; $m s p l$-mesopleuron; $m t c$-metacoxa; $m t p l$-metapleuron; $n$-neck of prothorax; oc-ocelli; $p c$-procoxa; $p l$-prothoracic lobe; $p r d$-propodeal disk; pre-propodeal end; prs-propodeal side; $s p$-spiracle; $t$-tegula; 1-6 (above)-abdominal nota; 1-6 (below)-abdominal sterna; 1 (below) is also the petiole.

2. Dorsal view of Podalonia valida (Cresson). $l m$-levator muscle; $m n-$ mesonotum; $p d$-propodeal disk; $p n$-pronotum; $p s$-propodeal side; $p s c$-postscutellum; sc-scutellum; sp-spiracle; $t$-tegula; $w$-wing; 1 -petiole (sternum of first abdominal segment as counted in this paper).

3. Usual form of clypeal margin in Podalonia violaceipennis (Lepeletier) female. $e$-compound eye; $f s$-side of frons between clypeus and eye.

4. Clypeal margin of Podalonia sonorensis (Cameron) female. $e$-compound eye.

5. Fore wing of Podalonia with names of the veins as used in this paper. $a$-anal; $b$-basal; $c$-costal; $c u$-cubital; $d$-discoidal; $f$-frenal fold; $m$-median; $p m$-posterior margin; $r$-radial; $r e_{1}$-first recurrent; $r e_{2}$-second recurrent; $s$-stigma; $s c$-subcostal; $s d$-subdiscoidal; $t c_{1}$-first transverse cubital; $t c_{2}$-second transverse cubital; $t c_{3}$ - third transverse cubital; $t m$-transverse median.

6. Hind wing of Podalonia with names of veins as used in this paper. $a-$ anal; $a x$-axillary; $c$-costal; $c u$-cubital; $d$-discoidal; $f$-fold; $f h-$ frenal hooks; $m$-median; $r$-radial; $s c$-subcostal; $s i$-sinus; $t c-$ transverse cubital; $t m$-transverse median.

7. Clypeus of Podalonia valida (Cresson) female. $e$-compound eye; $f_{S}-$ side of frons between clypeus and eye. 

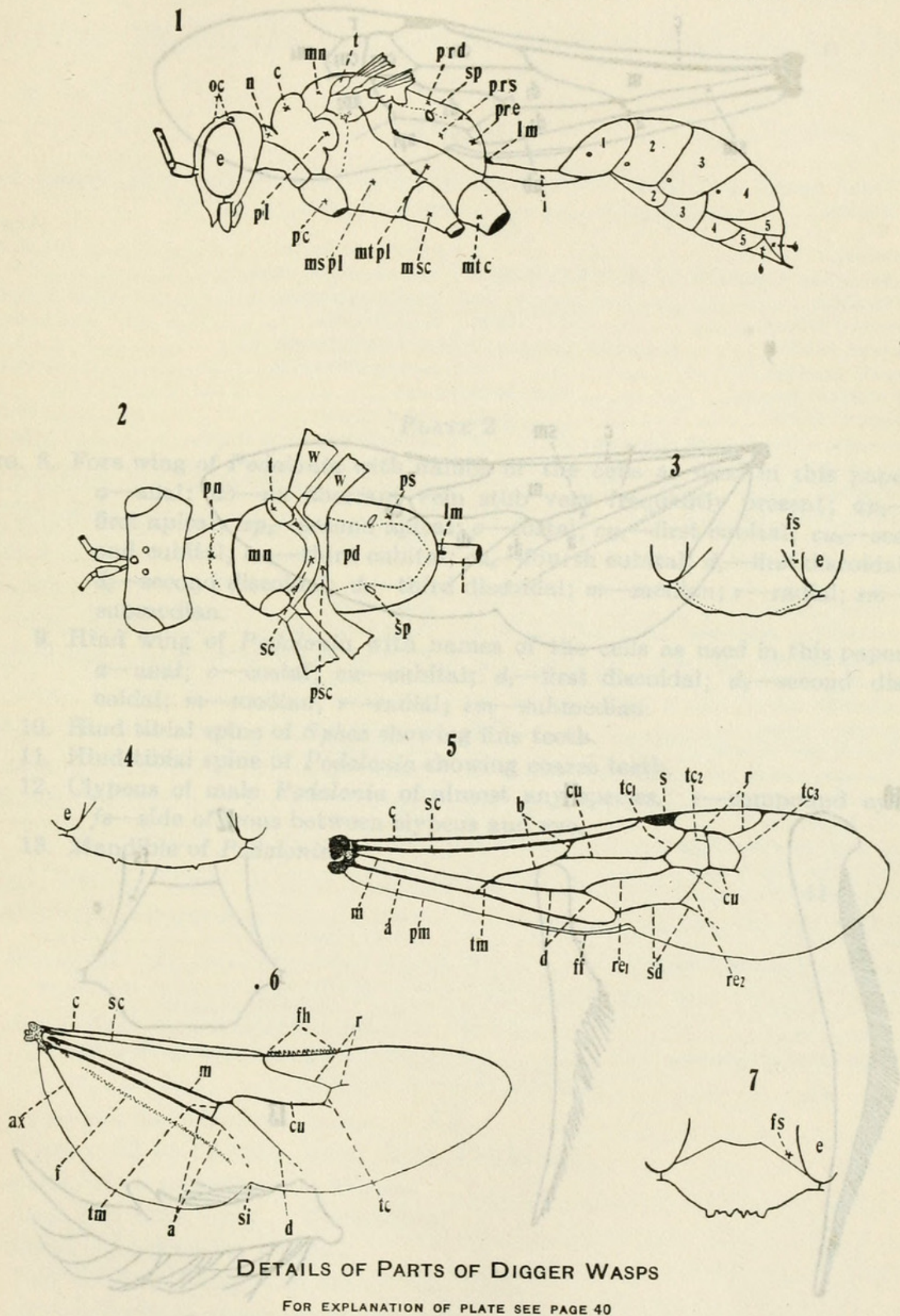

For EXPLANATION OF PLATE SEe PAgE 40 


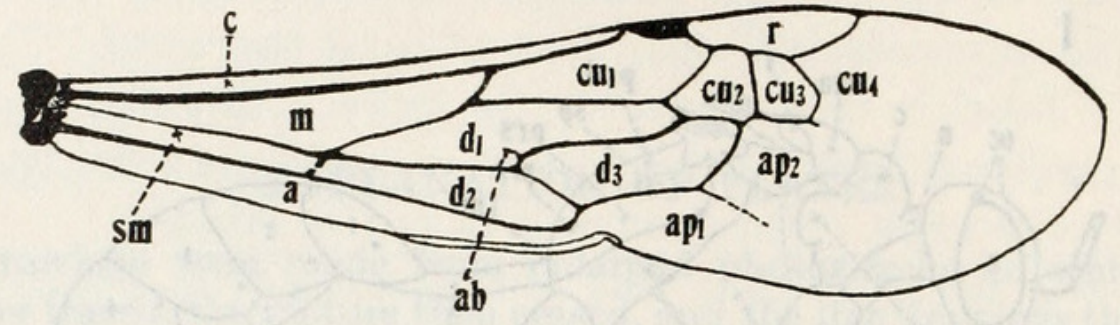

9
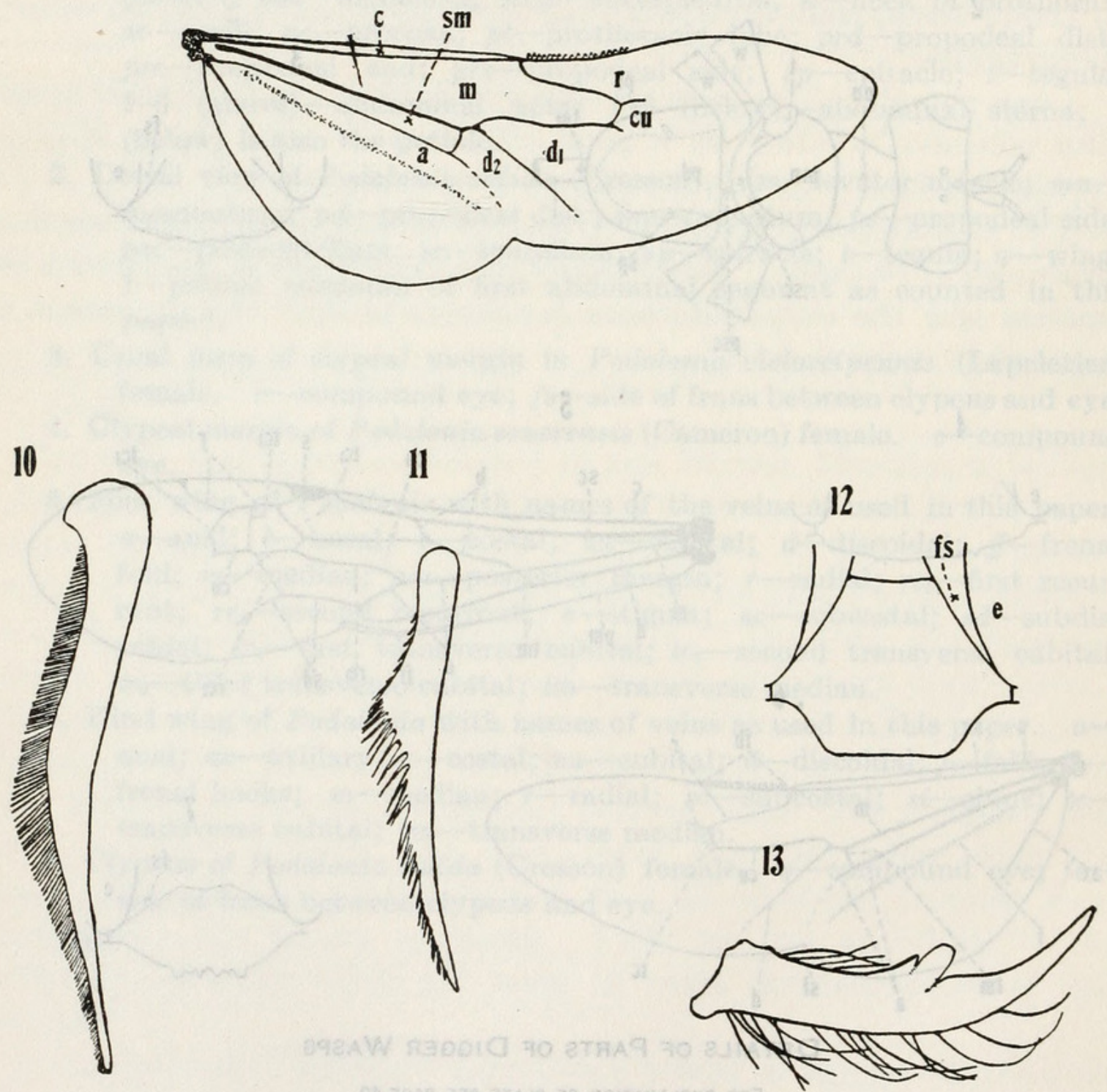

DETAILS OF PARTS OF DIGGER WASPS

For EXPLANATION OF PLATE SEE PAgE 41 


\section{$2 \mathrm{BHL}$ Biodiversity Heritage Library}

Fernald, H. T. 1927. "The digger wasps of North America of the genus Podalonia (Psammophila)." Proceedings of the United States National Museum 71(2681), 1-42. https://doi.org/10.5479/si.00963801.71-2681.1.

View This Item Online: https://www.biodiversitylibrary.org/item/32439

DOI: https://doi.org/10.5479/si.00963801.71-2681.1

Permalink: https://www.biodiversitylibrary.org/partpdf/32797.

\section{Holding Institution}

Smithsonian Libraries

\section{Sponsored by}

Smithsonian

\section{Copyright \& Reuse}

Copyright Status: NOT_IN_COPYRIGHT

Rights: https://www.biodiversitylibrary.org/permissions/

This document was created from content at the Biodiversity Heritage Library, the world's largest open access digital library for biodiversity literature and archives. Visit BHL at https://www.biodiversitylibrary.org. 